\title{
Maternal Dietary Quality and Dietary Inflammation Associations with Offspring Growth, Placental Development, and DNA Methylation
}

\author{
Marion Lecorguillé ${ }^{*}+{ }^{(D)}$, Shevaun Teo ${ }^{+}$(D) and Catherine M. Phillips (D) \\ School of Public Health, Physiotherapy and Sports Science, University College Dublin, Dublin 4, Ireland; \\ shevaun.teo@ucdconnect.ie (S.T.); catherine.phillips@ucd.ie (C.M.P.) \\ * Correspondence: marion.lecorguille@ucd.ie \\ + These authors contributed equally to this work.
}

Citation: Lecorguillé, M.; Teo, S.; Phillips, C.M. Maternal Dietary Quality and Dietary Inflammation Associations with Offspring Growth, Placental Development, and DNA Methylation. Nutrients 2021, 13, 3130. https://doi.org/10.3390/nu13093130

Academic Editor: Lynnette Ferguson

Received: 16 July 2021

Accepted: 4 September 2021

Published: 8 September 2021

Publisher's Note: MDPI stays neutral with regard to jurisdictional claims in published maps and institutional affiliations.

Copyright: (c) 2021 by the authors. Licensee MDPI, Basel, Switzerland. This article is an open access article distributed under the terms and conditions of the Creative Commons Attribution (CC BY) license (https:/ / creativecommons.org/licenses/by/ $4.0 /)$.
Abstract: The 'Developmental Origins of Health and Diseases' hypothesis posits that prenatal maternal diet influences offspring growth and later life health outcomes. Dietary assessment has focused on selected nutrients. However, this approach does not consider the complex interactions between foods and nutrients. To provide a more comprehensive approach to public health, dietary indices have been developed to assess dietary quality, dietary inflammation and risk factors for non-communicable diseases. Thus far, their use in the context of placental development is limited and associations with offspring outcomes have been inconsistent. Although epidemiological studies have focused on the role of maternal diet on foetal programming, the underlying mechanisms are still poorly understood. Some evidence suggests these associations may be driven by placental and epigenetic changes. In this narrative review, we examine the current literature regarding relationships between key validated diet quality scores (Dietary Inflammatory Index [DII], Mediterranean diet [MD], Healthy Eating Index [HEI], Alternative Healthy Eating Index [AHEI], Dietary Approaches to Stop Hypertension [DASH], Glycaemic Index [GI] and Glycaemic Load [GL]) in pregnancy and birth and long-term offspring outcomes. We summarise findings, discuss potential underlying placental and epigenetic mechanisms, in particular DNA methylation, and highlight the need for further research and public health strategies that incorporate diet quality and epigenetics.

Keywords: maternal dietary quality; dietary inflammatory index (DII); dietary scores; placental development; birth outcomes; childhood obesity; epigenetics

\section{Introduction}

The importance of adequate nutrition during foetal life for long-term health is well documented [1]. The 'Developmental Origins of Health and Diseases' (DOHaD) hypothesis postulates that maternal nutritional status in the preconception period and during pregnancy may influence offspring development and the occurrence of disease, from childhood to later life [2-5]. More recently, research in DOHAD shows that environmental factors can affect the development of the next generation even before conception and into early childhood (the first 1000 days-from conception to two years). The Dutch famine studies have reported that women who were undernourished during pregnancy had increased risk of having children with intrauterine growth retardation (IUGR) [2]. Smaller size or relative thinness at birth or during infancy has been related to increased rates of cardiovascular disease (CVD), type 2 diabetes mellitus (T2DM) and metabolic syndrome (MetS) in adulthood [5-8]. Much attention has focused on the conditions of nutritional deprivation, but there is new evidence that maternal obesity during pregnancy is associated with long-term health consequences for the offspring, such as increased body mass index (BMI) during infancy, childhood and later life and increased risk of T2DM in adulthood $[9,10]$. 
Adequate maternal nutritional intake is an essential factor for a healthy pregnancy and optimal child development. However, dietary assessment is difficult to elucidate due to its complex interactions between diverse foods and nutrients [11]. To provide a more comprehensive approach to public health prevention, several aspects of dietary intake are measured against dietary recommendations (defined as 'dietary quality') [12,13]. Pregnancy is also known to alter the maternal inflammatory state, and unfavourable levels of pro-inflammatory cytokines may be in turn associated with pregnancy complications and adverse birth outcomes [14]. Diet has been recognised as an important modulator of chronic inflammation. Furthermore, having a more anti-inflammatory or less pro-inflammatory diet may reduce adverse outcomes during pregnancy, particularly in obese women $[14,15]$.

Although epidemiological studies have focused on the role of maternal diet on foetal programming, underlying mechanisms are still poorly understood. Perturbations in the maternal environment may be transmitted across the placenta and thereby affect the development of the foetus. The placenta plays a fundamental role in maternal-foetal exchanges during pregnancy and an adequate maternal nutritional status is necessary to support placental homeostasis and development [16]. Altered placental structure and function may contribute to altered nutrient supply to the foetus [17].

Some evidence has shown that these associations may be also driven by epigenetic changes [18]. Epigenetic marks, in particular DNA methylation, appear to be particularly sensitive to environmental exposures during embryogenesis and cell differentiation $[18,19]$. Epigenetic data in humans are becoming increasingly robust but there is a challenge to continue exploring how specific factors (particularly nutritional factors in the prenatal period) may affect epigenetic mechanisms.

Thus, the aim of this narrative review is to examine and synthesize the literature regarding associations between maternal dietary quality, evaluated by several dietary scores, and dietary inflammation state with birth outcomes and long-term offspring health. We examine the underlying mechanisms including the placental dysfunction, which in turns impacts foetal growth, and the epigenetic mechanisms, more specifically DNA methylation, and conclude with future perspectives in this area of nutritional research

\section{Materials}

This is a narrative review of the current literature on the relationships between maternal dietary quality and dietary inflammation status and, birth and child outcomes, placental development and epigenetics. The literature search was performed in Pubmed, Web of Science, Scopus and the Cochrane database by using the following keywords separately or in combination: Maternal diet, nutrition, dietary inflammatory index, dietary quality scores (Dietary Inflammatory Index [DII], Mediterranean diet [MD], Dietary Approaches to Stop Hypertension [DASH], Healthy Eating Index [HEI], Alternative Healthy Eating Index [AHEI], Glycaemic Index [GI], Glycaemic Load [GL]), macronutrients, micronutrients, pregnancy, periconception period, foetal programming, child development, birth anthropometry, obesity, body mass index, placenta, epigenetic mechanisms, DNA methylation and cord blood. Relevant free-access abstracts were identified and peer-reviewed human studies, meta-analyses, systematic reviews and interventional studies were included. Other inclusion criteria were: (1) English language; (2) recording of the diet before or during pregnancy; (3) assessment of offspring measurements and prematurity; and (4) published papers within the last 15 years. Additionally, we included animal studies in our literature search in relation to maternal diet associations with placental outcomes and epigenetics. The websites of key government departments and agencies were consulted to identify important recommendations and reports such as the "Dietary Guidelines for Americans 2010".

\section{Maternal Diet and Indices of Dietary Quality and Dietary Inflammation}

Optimisation of maternal diet during critical windows of development may positively impact on childhood weight status and future health trajectory $[3,20]$. However, the spe- 
cific dietary requirements during pregnancy for optimal foetal growth and development are often limited in applicability and often prioritise macronutrient and micronutrient intake rather than food groups and dietary patterns. Most of the randomised controlled trials (RCTs) and observational studies have evaluated individual nutrient effects on foetal growth, with particular emphasis on avoiding certain micronutrient deficiencies [21,22]. Dietary patterns may provide a more comprehensive approach in public health for mother and infant as they have the potential to be used as a valid tool in assessing dietary associations with pregnancy outcomes $[11,23]$. Overall dietary quality may be more translatable to public health guidelines. Therefore, a variety of dietary scores and indices have been developed for nutritional epidemiology to assess dietary risk factors for non-communicable diseases [24-27]. These algorithms aim to evaluate the overall diet and categorise individuals according to the extent to which an individual's eating behaviour is "healthy" based on primary nutritional data collected from 24-h quantitative dietary intake recalls, dietary records and food frequency questionnaires (FFQs) [28]. More recently, the dietary inflammatory index $\left(\mathrm{DII}^{\circledR}\right)$, was developed to characterise the inflammatory potential of the diet $[25,29-31]$. Here we describe dietary components, patterns and scores that reflect dietary quality and inflammation and their relevance in pregnancy.

\subsection{Macronutrient Intakes in Pregnancy}

Macronutrients are broadly defined as nutrients that provide calories or energy and are required in large amounts to maintain body functions and carry out the activities of daily life [32,33]. During pregnancy, the maternal diet must provide an adequate supply of energy to support the mother's usual requirements as well as those of the growing foetus [21]. Extra energy is required for the synthesis of new tissue (foetus, placenta and amniotic fluid) and the growth of existing tissue (uterus, breast and maternal adipose tissue). Excessive energy intake should be avoided as it is the main determinant of gestational weight gain [21]. Hence, balancing and optimising protein and fibre as macronutrients could help with avoiding overnutrition during pregnancy, but these proportions need to be tailored based on pre-pregnancy weight, ethnicity, health literacy, BMI status and stage of pregnancy $[21,33,34]$. Special attention is warranted for the impact of carbohydrate intake in those with poor glycaemic control and at risk of gestational diabetes mellitus (GDM). During pregnancy, glucose transfer mainly occurs in the postprandial state, and glucose concentrations are determined by the carbohydrate foods $[35,36]$. The glycaemic index (GI) and glycaemic load (GL) qualify and quantify the postprandial glycaemic responses according to the dietary carbohydrate intake. Carbohydrates with low GI, for example whole grain breads, cereals and nuts, lead to a low glycaemic response, whereas foods such as confectionary and soft drinks lead to high glycaemic response [36,37]. Many systematic reviews have established the links between dietary GI/GL and the risk of chronic disease (such as T2DM, CVD and various cancers) but maternal carbohydrate quality has received relatively little attention [38,39]. Hence, further research is required in establishing the optimum timing to start a low-glycaemic index (GI) or glycaemic load (GL) diet for maximum protection against adverse pregnancy outcomes, in terms of insulin sensitivity, for both mother and infant [35,40].

\subsection{Micronutrient Intakes in Pregnancy}

Micronutrients are vitamins and minerals needed by the body in very small amounts to enable production of enzymes, hormones and other substances needed for normal growth and development [41,42]. Globally and even in high-income countries, an inadequate maternal micronutrient status is common with the evolution of food practices [41,43]. Studies in pregnant women in Germany and secundigravid women in Ireland showed that specific intakes of iron, folate vitamin $\mathrm{D}$, vitamin $\mathrm{B}_{12}$ and iodine were below national guidelines, thus highlighting that multiple micronutrient deficiencies can still be prevalent in developed countries and targeted supplementation may be required in certain groups [44,45]. For example, foetal hypothyroidism (most commonly caused by iodine deficiency) may 
need to be addressed in the European population where only 8 out of 21 countries showed an adequate iodine status (38\%) possibly due to low intake of iodine-rich seafood [46].

Folate is a key micronutrient for early stages of placental development [47] and the importance of periconceptional folate intake for child neurodevelopment has been widely recognised [48]. Folic acid supplementation is recommended in the preconception period (at least 3 months before becoming pregnant) and up to the 12th week of pregnancy, to prevent neural tube defects (NTD) and poor neurocognitive offspring outcomes [49-51].

Additionally, certain micronutrients are thought to play a role in epigenetic modification pathways including DNA methylation, thus establishing links between early nutrition programming and long-term health trajectories and disease risk [41,48]. Folate; vitamins $\mathrm{B}_{12}, \mathrm{~B}_{2}$, and $\mathrm{B}_{6}$; betaine; choline; and methionine implicated in one-carbon metabolism (OCM) have been found to change DNA methylation in foetal tissues and in the placenta $[19,48,52]$. Finally, it has been shown that multiple-micronutrient supplementation may have beneficial effects on the reduction of low birth weight (LBW) and small for gestational age (SGA), [21,22]. Thus, transitioning towards multiple-micronutrient supplementation with evaluation of dietary indices is key in improving placental and neurodevelopment offspring outcomes [21,22,41,53].

\subsection{Indices of Dietary Quality and Dietary Inflammation}

An overview of dietary indices commonly used in the general population is presented in Table 1. The development and construction of these scores in the general population and in pregnant women are discussed further below.

\subsubsection{Dietary Inflammatory Index (DII)}

First validated in 2009 (Generation 1) [31] and later refined in 2014 (Generation 2, a version that includes an improved scoring system and an updated, more complete literature search) by Shivappa et al. [29], the DII combines a range of macronutrients and micronutrients with various non-nutrient naturally occurring chemicals (e.g., caffeine, flavanols) and herbs and spices (such as onion, turmeric, saffron, thyme, rosemary and green and black tea) [29]. The score represents the overall inflammatory potential of an individual's diet based on 45 pro- and anti-inflammatory food parameters that either increased or decreased circulating biomarkers of inflammation (CRP, IL1 $\beta$, IL4, IL6, IL10 and $\mathrm{TNF} \alpha$ ). The index is calculated using a scoring algorithm; a higher score indicates a pro-inflammatory diet, and a lower score indicates an anti-inflammatory diet. Usually, the DII is expressed as an energy-adjusted DII (E-DII) score because relations between energy and nutrient consumption (a key aspect in determining overall inflammatory potential of the diet) varies across age and according to total body mass [30]. It can be derived from any dietary assessment tool (e.g., food records, national surveys) and is universally applicable across all human studies with adequate dietary assessment [30]. It is important to identify and interpret scoring ranges of the DII used in studies because when calculated from all the 45 food parameters, DII scores can range from -8.87 to +7.98 . To incorporate consistency in its interpretation, DII scores derived from 25-30 food parameters would lead to a more effective range of -5.5 to +5.5 [30]. Regardless, it is known that the effective range should rarely exceed 11 [30]. In this review, we focus on offspring associations with the refined (Generation 2) DII. 
Table 1. Summary of Dietary Metric Components.

\section{Dietary Score Food Components and Calculation}

Literature-based index measuring the effect of 45 food parameters (a mix of macro- and micro-nutrien food components such as alcohol; vitamin B12;

Dietary Inflammatory Index (DII)

[30] $\beta$-carotene; caffeine; carbohydrate; cholesterol; fibre folic acid; garlic; ginger; iron; monounsaturated fat) on six inflammatory biomarkers (IL-1 $\beta$, IL-4, IL-6, IL-10, TNF- $\alpha$ and C-reactive protein).

\section{Interpretation}

Higher values of the DII indicate a

pro-inflammatory (i.e., less healthy) dietary

profile, whereas lower values indicate an

anti-inflammatory (i.e., more healthy) dietary profile. Using the energy-adjusted DII (E-DII)

score is often more reliable as it is associated

with improved prediction in comparison to unadjusted DII scores.

Varying food components across different indices. Most useful indices base calculation of 9 components:

- High intake of the non-Mediterranean foods: dairy and meat were scored negative as (0)

Mediterranean Diet (MD) $[54,55]$

- High intake of Mediterranean foods: cereals,

legumes, fruit, vegetables, fish, Monounsaturated fatty acids to Saturated fatty acids (MUFA-SFA) ratio, and wine which were scored positive as (1)

12 components in total 9 adequacy components: Total Fruit, Whole Fruit (forms other than juice), Total

Vegetables, Greens and Beans (dark-green vegetables and beans and peas), Whole Grains, Dairy (all milk products and soy beverages), Total Protein Foods,
Healthy Eating Index 2010 (HEI-2010)

[56]

Seafood and Plant Proteins, and Fatty Acids (ratio of polyunsaturated fatty acids [PUFA] and MUFA to SFA). Scored 10 in the highest consumption and 0 in the lowest.

3 moderation components are: Refined Grains, Sodium, and Empty Calories (all calories from solid fats \& added sugars plus calories from alcohol

beyond a moderate level) scored 10 in the lowest consumption
A metric indicating compliance to the

Mediterranean diet pattern in adults.

Across the different MD indices, ranges calculated that generate higher values indicate greater MD adherence.

A score of $0-3$ represents low adherence, a score of 4-6 represents moderate adherence to the Mediterranean diet and a score of 7-9 represents high adherence

Measure of overall diet quality that measures alignment with the 2010 Dietary Guidelines for Americans

Scored on a density basis out of 1000 calories An HEI as "needing dietary improvement"

\section{Food Frequency Questionnaire}

\section{Dietary Assessment Method}


Table 1. Cont.

Dietary Score

Food Components and Calculation

\section{3 components in tota}

The HEI-2015 components are the same as in the

HEI-2010, except Saturated Fat and Added Sugars

HEI-2015

[57]

replace Empty Calories. Previous versions of the HEI

accounted for legumes in either the two vegetable or

the two protein foods components, whereas HEI-2015

counts legumes toward all four components.

AHEI-2010

$[58,59]$

\section{1 components in total:}

Vegetables; fruit; whole grains; sugar-sweetened

beverages; nuts and legumes; red and processed

meat; trans fats; long-chain (n-3) fatty acids

(eicosapentaenoic acid and docosahexaenoic acid);

polyunsaturated fatty acid; sodium; alcohol

8 components: Fruit, vegetables, nuts and legumes,

whole grains, low-fat dairy products, sodium, red

and processed meats, and sweetened beverages

The lowest intake of healthy components (fruits,

Dietary Approaches to Stop

Hypertension

(DASH)

$[60,61]$

vegetables, nuts and legumes, low-fat dairy products,

and whole grains) receive one point and the top quintile receives 5 points

The scoring for the remaining unhealthy components

is reversely coded so that quintile 1 receives 5 points and quintile 5 receives one point

Glycaemic index and load

(GI and GL)

[62]
GI is a way of ranking carbohydrate foods based on the rate at which they raise blood glucose levels.

GL estimates the impact of carbohydrate intake using the GI while accounting for serving size. $\mathrm{GL}=\mathrm{GI} \times$ carbohydrate in a serving $/ 100$

\section{Interpretation}

Dietary Assessment Method

Measure of overall diet quality that measures alignment with the updated 2015-2020

Dietary Guidelines for Americans that are scored on a density basis out of 1000 calories.

A HEI score between 51 and 80 is considered as "needing dietary improvement"

Food Frequency Questionnaire

An alternative version of the HEI that focuses

on adherence to a dietary pattern associated

with chronic disease risk and pays more

attention to fat quality (i.e., intakes of omega-3

fats and polyunsaturated fats)

Assess diet adequacy and moderation

Sex-specific intake quintiles are generated for each of the 8 components.

The overall score ranges from 8 (the lowest adherence) to 40 (the highest adherence)

Food Frequency Questionnaire

Foods that are digested quickly (e.g., refined, starchy grains and fruit juices) will raise blood glucose levels quickly and therefore are given

$$
\text { higher GI/GL values }
$$

A GL classification system is used in which

foods are categorized as having low $(\leq 10)$

medium $(>10-<20)$ or high GL $(\geq 20)$ 


\subsubsection{Mediterranean Diet (MD)}

Several dietary metrics based on the MD have been created including the Mediterranean Diet Scale (MDScale) developed by Trichopoulou et al., Mediterranean Food Pattern (MFP), the MD Score (MDS), Mediterranean Lifestyle (MEDLIFE) index and the MedDiet score [54,55]. The Mediterranean dietary metric is based on epidemiologic findings of beneficial dietary effects on cardiovascular health, often localised to healthy eating guidelines [63]. The traditional main components are vegetables, legumes, fruits and nuts, unrefined cereals, olive oil, a moderate intake of fish, low to moderate intake of dairy products, a low intake of meat and poultry and moderate alcohol intake during meals. Differences noted between the various MD scores include number of components (nutrients, foods or food groups intake); classification categories for each item; measurement scales; statistical parameters (mean, median or tertiles of daily intake) and the contribution of each component (positive or negative) to the total score.

\subsubsection{Healthy Eating Index (HEI)}

Originally developed in 1995, the HEI evaluated adherence to key dietary recommendations from the Dietary Guidelines for Americans [64]. The original HEI was used to measure the overall dietary quality, but since then, the HEI has been modified regularly to reflect changes in dietary recommendations [65]. From 2005, the United States Department of Agriculture (USDA) versions of the HEI were based on an energy density approach $[43,66]$. The HEI-2010 score includes 12 components: 9 assess dietary adequacy (foods that people should consume more of) and 3 assess moderation (foods that people should consume less of) [56]. The HEI-2015 is the most recent iteration based on conformance with the 2015-2020 Dietary Guidelines for Americans [57]. The HEI-2015 uses a scoring system to evaluate food groups. Scores above 80 indicate a "good" diet, while scores below 51 indicate a "poor" diet [58]. An HEI score between 51 and 80 is considered as "needing dietary improvement". The HEI-2010 and 2015 components are similar with the following exceptions in the HEI-2015: Saturated fat and added sugars replace empty calories and legumes are allocated to the two vegetable and the two protein foods components (thus highlighting the importance of a varied, balanced diet). Considering the overall similarities of the HEI-2010 and 2015 scores, similar diet-disease associations may be expected with both scores.

\subsubsection{Alternative Healthy Eating Index (AHEI)}

Compared to the HEI, the AHEI-2010 incorporates foods, nutrients, dietary recommendations predictive of chronic disease risk (i.e., T2DM) and mortality [58]. It consists of 11 components of varying proportions: Six components for which higher intakes are better (vegetables, fruit, wholegrains, nuts and legumes, long chain omega- 3 fatty acids (FA) that include docosahexaenoic acid (DHA) and eicosapentaenoic acid (EPA) and polyunsaturated fatty acids (PUFA)); one component for which moderate intake is better (alcohol); and four components that must be limited or avoided (sugar sweetened drinks and fruit juice, red and processed meat, trans fats and sodium) [58]. Hence, the AHEI emphasises diet (predominantly fat) quality (i.e., intakes of omega-3 FAs and PUFAs) and promotes the intake of nuts and legumes using a food-based dietary guideline approach. This could be important in reducing adverse outcomes for infants for women who are at greater risk of gestational diabetes and hypertensive disorders of pregnancy $[58,66]$. In addition, the AHEI-2010 recommends limiting the intake of red and processed meats and to avoid added sugars (i.e., sugar-sweetened beverages and fruit juice), both of which have been associated with pro-inflammatory states and the risk of overnutrition coming from excess prenatal sugar intakes $[67,68]$.

\subsubsection{Dietary Approaches to Stop Hypertension (DASH)}

The DASH score was developed for the therapeutic reduction in blood pressure based on dietary patterns and food/nutrient components from the DASH Trial [61]. It 
is promoted as a healthy option for the general population as a therapeutic means of controlling high blood pressure without the use of medication. The DASH score created by Fung et al. [60] is the most commonly used dietary score in the literature and is relevant to the pregnant population as it was calculated based on a middle-aged female population in the US (a Western developed, industrialised nation) $[60,69]$. It uses scoring based on the quintile distribution of intake on the following eight components: A high consumption of fruits, vegetables, nuts and legumes; low-fat dairy products and whole grains; and a low consumption of sodium, sweetened beverages and red and processed meats [26]. A DASH score between 8 to 40 (indicative of lowest and highest adherence respectively) ranks participants according to their dietary intakes.

\subsubsection{Modified Dietary Scores for Pregnancy}

Many of the aforementioned dietary scores have been modified and adapted for characterising maternal diet quality during pregnancy. Mediterranean diet scores such as Trichopolou's MDS and Khoury's score have often been modified in observational studies for pregnancy to provide the most useful information in terms of conceptual suitability and applicability [55]. For example, the original a priori Trichopolou's MDS and the KIDMED index (another MD score validated in younger individuals [2-24 years]) have been modified to consider dairy to be protective due to increased calcium requirements during pregnancy and hence is scored positively [70-72], whereas nuts can sometimes be excluded from dietary scores (Khoury and AHEI for pregnancy) as some women may avoid nuts during pregnancy out of concern for allergen sensitisation [73-75]. The HEI-SGP (generated based on dietary guidelines and recommendations for pregnant women in Singapore) and the Alternate Healthy Eating Index for Pregnancy (AHEI-P) are conceptually similar to the standard HEI except they include adherence to antenatal supplementation of key micronutrients (iron, folate and calcium) in their scoring $[20,75,76]$. These scores have been shown to be useful in identifying women 'at risk' of poor blood glucose control and pre-eclampsia during pregnancy, who would benefit from early intervention with multiplemicronutrient supplementation $[75,76]$. The DASH dietary pattern, modified in line with trends observed in the pregnant population such as limiting sugar-sweetened beverage intake, has also been shown to improve glucose tolerance and lipid profiles of women with GDM $[77,78]$. In the ROLO study, a DASH dietary pattern during pregnancy was associated with lower maternal blood pressure among healthy women without hypertensive disorders of pregnancy [79].

In summary, these specific dietary metrics all share certain characteristics such as a diet high in vegetables, legumes and fruits, indicative of better diet quality and sustained habits, and were associated with one or more important maternal health outcomes such as preeclampsia, GDM, altered blood glucose metabolism and postpartum obesity [70,75,79-83]. Additionally, most of these pregnancy-specific dietary tools account for adequacy of key food groups and micronutrients that favour maternal and child health and can serve as useful tools to indicate adherence to national healthy eating recommendations $[20,75,76,84]$.

\section{Maternal Dietary Metrics and Offspring Birth Outcomes}

As mentioned above, studies investigating maternal diet have mainly focused on adequate intake of selected macronutrients and micronutrients during pregnancy. In recent years, there has been growing interest in examining associations between overall maternal diet quality (by using the previously described scores) and child development. Here we summarise the literature regarding the relationship between maternal dietary quality and dietary inflammatory potential with birth outcomes related to growth and prematurity.

\subsection{Dietary Inflammatory Index}

Chronic inflammation during pregnancy that is observed in obese women may alter physiological mechanisms of the developing foetus. Obesity-induced inflammation is characterised by abnormal cytokine and adipokine levels [85]. Some studies have shown 
that a higher DII or E-DII score indicating a more anti-inflammatory diet may ameliorate the pro-inflammatory state of pregnancy, particularly in obese women [14,15]. A detailed description of the studies outlined below is reported in Table 2. The Healthy Start Study ( $n=1078$ mother-neonate pairs) reported that higher DII scores in obese mothers during pregnancy were associated with increased neonatal adiposity [86], while the NEST study ( $n=1057$ mother-child pairs) did not report associations with birth anthropometry but an increased risk of prematurity among female offspring was observed [14]. Conversely, in the Lifeways study, higher maternal E-DII scores in early pregnancy were associated with increased risk of low birthweight [24]. Additionally, results from the Project VIVA showed that higher DII scores were associated with lower birth weight for gestational age $z$ score in infants born to obese mothers [15]. There are limited investigations of maternal DII and its influence on birth outcomes, and results remain inconsistent. However, a recent metaanalysis of individual participant data on 24,861 mother-child pairs, in seven European cohorts, has been recently conducted [87]. A higher maternal pre-pregnancy E-DII score was associated with lower birth weight $[\beta(95 \% \mathrm{CI})=-18.7(-34.8,-2.6) \mathrm{g}$ per 1-SD higher E-DII score] and shorter birth length $[-0.07(-0.14,-0.01) \mathrm{cm}]$, whereas a higher E-DII score during pregnancy was associated with an increased risk of LBW [odds ratio (OR) $(95 \% \mathrm{CI})$ $=1.14(1.04,1.26)$ and being small for gestational age (SGA) $[\mathrm{OR}(95 \% \mathrm{CI})=1.18(1.11,1.26)]$ and shorter birth length $[-0.06(-0.10,-0.01) \mathrm{cm}$. These findings, which were robust across a range of sensitivity analyses, highlight the importance of having a less pro-inflammatory diet not only during pregnancy but also before becoming pregnant.

\subsection{Mediterranean Diet}

Some studies have examined the potential benefits of the Mediterranean diet on foetal development, considering the MD as a whole rather than focusing on the effect of its individual components. Foetal growth restriction (FGR) and SGA were the main outcomes examined. In a prospective observational study of 3207 Caucasian pregnant mothers in Rotterdam, low adherence to a MD in early pregnancy was associated with decreased intra-uterine size with a lower placental and a lower birth weight [88]. Inversely, in the INMA-Mediterranean cohort in Spain, mothers with high MD adherence had a significantly lower risk of having foetal growth restricted infant at birth [89]. However, the previous results were not consistent in the INMA study from the Atlantic area and the RHEA cohort in Greece [89]. One limitation of these studies is that the MD is subject to some regional variations associated with sociocultural, population and geographic differences. MD scores during pregnancy were not homogeneous, with women in the Atlantic area reporting higher intakes of fish and dairy products, while women in Greece reported higher intakes of fruits and nuts. These observations could explain in part the different results in population. However, in all cohorts, they showed a protective effect of adherence to MD in smokers that may counter the effect of oxidative stress damage on foetal tissues [89]. 
Table 2. Individual studies on the associations between maternal dietary inflammation determined by the DII and E-DII and birth outcomes.

\begin{tabular}{|c|c|c|c|c|c|c|c|}
\hline First Author, Year & Country or Setting & Study Design & Population & $\begin{array}{l}\text { Dietary Assessment Method } \\
\text { and Period }\end{array}$ & Assessment of Adherence to the Diet & Birth Outcomes & Key Findings \\
\hline $\begin{array}{c}\text { Navarro et al., } 2019 \\
{[24]}\end{array}$ & Ireland, 2001-2003 & $\begin{array}{c}\text { Lifeways } \\
\text { Cross-Generation } \\
\text { Cohort Study: A } \\
\text { prospective family study }\end{array}$ & 1082 mother-child pairs & $\begin{array}{l}\text { Semi-quantitative Food } \\
\text { frequency questionnaires (FFQ), } \\
\text { consumption during the first } \\
12-16 \text { weeks of pregnancy }\end{array}$ & $\begin{array}{l}\text { Calculation of E-DII score based on } 28 \\
\text { food parameters: carbohydrate, protein, } \\
\text { fat, alcohol, fibre, cholesterol, saturated } \\
\text { fat, } \\
\text { mono-unsaturated fat, poly-unsaturated } \\
\text { fat, niacin, thiamin, riboflavin, vitamin } \\
\text { B12, vitamin B6, iron, magnesium, zinc, } \\
\text { selenium, beta-caro- } \\
\text { tene, vitamin A, vitamin C, vitamin D, } \\
\text { vitamin E, folic acid, onion, garlic, tea } \\
\text { and caffeine. }\end{array}$ & $\begin{array}{l}\text { Low birthweight, } \\
\text { macrosomia, per-term } \\
\text { and post-term birth }\end{array}$ & $\begin{array}{l}\text { Higher maternal E-DII } \\
\text { scores were associated } \\
\text { with increased risk of } \\
\text { low birthweight } \\
\text { Higher maternal } \\
\text { grandmothers E-DII } \\
\text { scores were associated } \\
\text { with increased risk of } \\
\text { macrosomia }\end{array}$ \\
\hline Moore et al., 2018 [86] & USA, 2009-2014 & $\begin{array}{l}\text { Healthy Start study: A } \\
\text { prospective pre-birth } \\
\text { cohort. }\end{array}$ & $\begin{array}{c}1078 \text { mother-child-pairs } \\
\text { with neonates born } \geq 32 \\
\text { weeks of gestation, and } \\
\text { mothers with } \\
\text { pre-pregnancy } \\
\text { BMI } \geq 18.5 \mathrm{~kg} / \mathrm{m}^{2}\end{array}$ & $\begin{array}{l}\text { Repeated 24-h dietary recalls } \\
\text { completed each month during } \\
\text { pregnancy }\end{array}$ & $\begin{array}{c}\text { DII scores based on } 28 \text { components: } \\
\text { energy, total fat, saturated fat, } \\
\text { monounsaturated fat, polyunsaturated } \\
\text { fat, omega-3 polyunsaturated fatty acids, } \\
\text { omega-6 fatty acids, trans-fat, } \\
\text { carbohydrates, fiber, protein, cholesterol, } \\
\text { iron, Vitamin A, Vitamin C, Vitamin D, } \\
\text { Vitamin E, niacin, thiamin, riboflavin, } \\
\text { Vitamin B6, Vitamin B12, folic acid, } \\
\text { magnesium, zinc, selenium, alcohol and } \\
\text { caffeine }\end{array}$ & $\begin{array}{l}\text { Birth weight, fat mass, } \\
\text { fat-free mass and } \\
\text { percent fat mass, small } \\
\text { and large for gestational } \\
\text { age (LGA) }\end{array}$ & $\begin{array}{c}\text { Among neonates born to } \\
\text { obese women, each } \\
\text { one-unit increase in DII } \\
\text { was associated with } \\
\text { increased birth weight, } \\
\text { fat mass and percent fat } \\
\text { mass } \\
\text { One-unit increase in DII } \\
\text { score was associated } \\
\text { with a tendency of } \\
\text { increased risk of having } \\
\text { a LGA infant }\end{array}$ \\
\hline $\begin{array}{l}\text { Sen et al., } 2016 \\
{[15]}\end{array}$ & USA, 1999-2002 & $\begin{array}{l}\text { Project Viva, a pre-birth } \\
\text { cohort study }\end{array}$ & $\begin{array}{c}1808 \text { mother-child pairs } \\
\text { with a pre-pregnancy } \\
\left.\text { BMI (in } \mathrm{kg} / \mathrm{m}^{2}\right) \geq 18.5 \\
\text { without pre-existing } \\
\text { type } 1 \text { or } 2 \text { diabetes } \\
\text { mellitus }\end{array}$ & $\begin{array}{l}\text { FFQ administered at the first } \\
\text { and second trimester }\end{array}$ & $\begin{array}{c}\text { DII based on } 28 \text { components: } \\
\text { energy, carbohydrate, protein, fat, } \\
\text { alcohol, fibre, cholesterol, SFAs, MUFAs, } \\
\text { PUFAs, n- } 3 \text { and n-6 FAs, trans-fat, niacin, } \\
\text { thiamin, riboflavin, vitamin B-12, } \\
\text { vitamin B-6, iron, magnesium, zinc, } \\
\text { selenium, vitamin A, vitamin } \mathrm{C} \text {, vitamin } \\
\text { D, vitamin E, folic acid and } \beta \text {-carotene. }\end{array}$ & $\begin{array}{l}\text { Birth weight for } \\
\text { gestational age, } \\
\text { premature birth }\end{array}$ & $\begin{array}{l}\text { Higher DII scores were } \\
\text { associated with lower } \\
\text { birth weight for } \\
\text { gestational age } z \text { score in } \\
\text { infants born to obese } \\
\text { mothers }\end{array}$ \\
\hline
\end{tabular}


Other studies reported associations between maternal MD and prematurity. In a study from the French West Indies, where dietary patterns present several characteristics of the MD diet, no overall associations were found between MD adherence and birth weight. However, there was a decreased risk of prematurity associated with greater MD in overweight and obese women [90]. In the observational cohort of 35,530 Danish women, Mikkelsen et al. showed a $72 \%$ reduction in the risk of early preterm delivery $(<35$ weeks of gestation) in women who fulfilled all MD criteria, compared to women fulfilling none of the MD criteria during pregnancy [91]. Meanwhile, another study in Norway, which defined MD with the same criteria as the previous study, showed no association with risk of prematurity [73]. However, several hypotheses explaining the potential link with reduced risk of prematurity have been described. In particular, one randomized trial has evaluated the effect of a cholesterol-lowering diet on maternal pregnancy outcomes. In that study, women in the intervention group were advised to change their diet towards a Mediterranean-type diet. A diet enriched with n-3 (omega-3) PUFA may influence the level of inflammatory cytokines, which are involved in the pathophysiological mechanisms of prematurity and reduced its incidence [74]. Most studies focused on evaluating birth weight or prematurity; however, a recent study showed that greater MD adherence was positively associated with birthweight, length and sum of skinfold thickness, a measure that better captures total neonatal adiposity [92]. A detailed description of the previous articles (non-exhaustive list) is reported in Table 3. 
Table 3. Individual studies on the associations between maternal dietary quality determined by the Mediterranean diet score and birth outcomes.

\begin{tabular}{|c|c|c|c|c|c|c|c|}
\hline First Author, Year & $\begin{array}{l}\text { Country or } \\
\text { Setting }\end{array}$ & Study Design & Population & $\begin{array}{l}\text { Dietary Assessment } \\
\text { Method and Period }\end{array}$ & $\begin{array}{c}\text { Assessment of } \\
\text { Adherence to the Diet }\end{array}$ & Birth Outcomes & Key Findings \\
\hline Yisahak et al., 2021 [92] & $\begin{array}{c}\text { USA, } \\
\text { 2009-2013 }\end{array}$ & $\begin{array}{l}\text { Eunice Kennedy Shriver } \\
\text { National Institute of Child } \\
\text { Health and Human } \\
\text { Development Fetal Growth } \\
\text { Studies-Singletons: } \\
\text { Prospective cohort }\end{array}$ & 2802 pregnant women & FFQ in first trimester & Trichopoulou's score [71] & $\begin{array}{c}\text { Birthweight, length, upper } \\
\text { arm length, head } \\
\text { circumference, abdominal } \\
\text { circumference, sum of } \\
\text { skinfold thick-ness, } \\
\text { prematurity, SGA, LGA, } \\
\text { low birth weight (LBW), } \\
\text { macrosomia }\end{array}$ & $\begin{array}{l}\text { Greater MD is associated } \\
\text { with higher birthweight, } \\
\text { reduced odds of LBW, } \\
\text { increased birth length, } \\
\text { upper arm length, } \\
\text { significant p-trend for sum } \\
\text { of skinfolds }\end{array}$ \\
\hline $\begin{array}{c}\text { Peraita-Costa et al., } 2020 \\
\text { [93] }\end{array}$ & Spain, 2018-2019 & $\begin{array}{l}\text { Two-phase retrospective } \\
\text { population-based study }\end{array}$ & $\begin{array}{l}1118 \text { mother-child pairs } \\
\text { admitted after delivery }\end{array}$ & $\begin{array}{l}\text { Semi-quantitative FFQ (16 } \\
\text { items), self-administered } \\
\text { after delivery }\end{array}$ & Kidmex scores [72] & SGA and preterm birth & $\begin{array}{l}\text { Medium adherence to MD } \\
\text { was associated with a } \\
\text { higher risk of giving birth } \\
\text { to a preterm newborn. } \\
\text { No association was found } \\
\text { between MD adherence } \\
\text { and SGA }\end{array}$ \\
\hline $\begin{array}{c}\text { Martinez-Galiano et al., } \\
2018 \text { [94] }\end{array}$ & Spain, 2012-2015 & $\begin{array}{c}\text { Prospective multicentre } \\
\text { matched case-control study } \\
\text { (The matching criterion } \\
\text { was the maternal age at } \\
\text { delivery) }\end{array}$ & $\begin{array}{l}518 \text { mothers of singleton } \\
\text { SGA infants, } 518 \text { mothers } \\
\text { of singleton infants with } \\
\text { normal weight for } \\
\text { gestational age }\end{array}$ & $\begin{array}{c}\text { Semi-quantitative FFQ, } \\
\text { administered } 2 \text { days after } \\
\text { delivery }\end{array}$ & $\begin{array}{l}\text { PREDIMED score [95], } \\
\text { Trichopoulou's score [71], } \\
\text { Panagiotakos' score [96] }\end{array}$ & $\begin{array}{l}\text { Small for gestational-age } \\
\text { (SGA) risk }\end{array}$ & $\begin{array}{l}\text { MD adherence was } \\
\text { associated to a reduced } \\
\text { risk of SGA in newborns }\end{array}$ \\
\hline $\begin{array}{c}\text { Gomez-Roig et al., } 2017 \\
\text { [97] }\end{array}$ & Spain, over 14 months & Cross-sectional study & $\begin{array}{c}46 \text { mothers with SGA } \\
\text { foetuses, } 81 \text { mothers with } \\
\text { appropriate for gestational } \\
\text { age (AGA) foetuses }\end{array}$ & $\begin{array}{l}\text { Semi-quantitative FFQ, } \\
\text { administered during the } \\
\text { third trimester }\end{array}$ & Trichopoulou's score [71] & SGA risk & $\begin{array}{l}\text { Mothers maintaining a } \\
\text { Mediterranean-type diet } \\
\text { were more likely to have } \\
\text { an AGA foetus }\end{array}$ \\
\hline Saunders et al., 2014 [90] & $\begin{array}{l}\text { French Caribbean Island } \\
\text { (Guadeloupe), 2004-2007 }\end{array}$ & $\begin{array}{l}\text { TIMOUN Study: } \\
\text { Prospective mother-child } \\
\text { cohort study }\end{array}$ & $\begin{array}{l}728 \text { pregnant women with } \\
\text { a live-born singleton } \\
\text { pregnancy without major } \\
\text { congenital malformations }\end{array}$ & $\begin{array}{l}\text { Semi-quantitative FFQ, } \\
\text { diet during pregnancy }\end{array}$ & Trichopoulou's score [71] & $\begin{array}{l}\text { Preterm delivery and risk } \\
\text { of foetal growth restriction } \\
\text { (FGR) }\end{array}$ & $\begin{array}{l}\text { No association between } \\
\text { MD adherence during } \\
\text { pregnancy and the risk of } \\
\text { prematurity or FGR } \\
\text { MD adherence was } \\
\text { associated with a } \\
\text { decreased risk of } \\
\text { prematurity specifically in } \\
\text { overweight and obese } \\
\text { women }\end{array}$ \\
\hline $\begin{array}{c}\text { Timmermans et al., } 2012 \\
\text { [88] }\end{array}$ & Netherlands, 2001-2006 & $\begin{array}{c}\text { Generation R study, } \\
\text { prospective } \\
\text { population-based cohort } \\
\text { study }\end{array}$ & $\begin{array}{l}3207 \text { mothers with a } \\
\text { spontaneously conceived } \\
\text { live-born singleton } \\
\text { pregnancy }\end{array}$ & $\begin{array}{c}\text { Semi quantitative } \mathrm{FFQ}, \\
\text { Early pregnancy }<18 \\
\text { weeks }\end{array}$ & $\begin{array}{l}\text { Dietary pattern identified } \\
\text { and labelled MD as it was } \\
\text { characterized by higher } \\
\text { intakes of pasta, rice, } \\
\text { vegetable oils, fish, } \\
\text { vegetables and alcohol, } \\
\text { and lower intakes of meat, } \\
\text { potatoes and fatty sauces }\end{array}$ & $\begin{array}{l}\text { Foetal growth, placenta } \\
\text { development }\end{array}$ & $\begin{array}{l}\text { Low MD adherence } \\
\text { resulted associated with } \\
\text { lower birth weight and } \\
\text { placental weight }\end{array}$ \\
\hline
\end{tabular}


Table 3. Cont.

\begin{tabular}{|c|c|c|c|c|c|c|c|}
\hline First Author, Year & $\begin{array}{l}\text { Country or } \\
\text { Setting }\end{array}$ & Study Design & Population & $\begin{array}{l}\text { Dietary Assessment } \\
\text { Method and Period }\end{array}$ & $\begin{array}{l}\text { Assessment of } \\
\text { Adherence to the Diet }\end{array}$ & Birth Outcomes & Key Findings \\
\hline $\begin{array}{c}\text { Chatzi et al., } 2011 \\
\text { [89] }\end{array}$ & $\begin{array}{l}\text { Spain 2004-2007, Greece } \\
\text { 2007-2008 }\end{array}$ & $\begin{array}{l}\text { INMA (Spain) and RHEA } \\
\text { (Crete) cohorts: } \\
\text { Prospective } \\
\text { population-based cohort } \\
\text { study }\end{array}$ & $\begin{array}{c}\text { Spain: } 2461 \\
\text { mother-newborn pairs. } \\
\text { Greece: } 889 \\
\text { mother-newborn pairs }\end{array}$ & $\begin{array}{l}\text { Semi-quantitative FFQ, } \\
\text { administered during first } \\
\text { (IMNA cohort) or mid } \\
\text { trimester (RHEA cohort) of } \\
\text { pregnancy }\end{array}$ & $\begin{array}{c}\text { Trichopoulou's score } \\
\text { modified for pregnancy } \\
\text { [71] }\end{array}$ & Foetal growth & $\begin{array}{l}\text { INMA-Mediterranean } \\
\text { cohort: high MD } \\
\text { adherence was associated } \\
\text { with higher BW and } \\
\text { reduced risk of foetal } \\
\text { growth restriction } \\
\text { In all cohorts, high MD } \\
\text { increased birth weight in } \\
\text { smoking mothers }\end{array}$ \\
\hline Mikkelsen et al., 2010 [91] & Denmark, 1996-2002 & $\begin{array}{l}\text { Danish National Birth } \\
\text { Cohort: prospective cohort } \\
\text { study }\end{array}$ & $\begin{array}{c}35657 \text { pregnant women } \\
\text { with a live-born singleton } \\
\text { pregnancy }\end{array}$ & $\begin{array}{c}\text { Semi-quantitative } F F Q, \\
\text { self-administered at mid } \\
\text { pregnancy }\end{array}$ & Khoury's score [74] & Preterm delivery & $\begin{array}{l}\text { Reduced risk of early } \\
\text { preterm delivery in MD } \\
\text { women }\end{array}$ \\
\hline Haugen et al., 2008 [73] & Norway, 2002-2005 & $\begin{array}{l}\text { Norwegian Mother and } \\
\text { Child Cohort Study } \\
\text { (MoBa): prospective cohort } \\
\text { study }\end{array}$ & $\begin{array}{l}26563 \text { pregnant women } \\
\text { with a live-born singleton } \\
\text { pregnancy }\end{array}$ & $\begin{array}{c}\text { Semi quantitative } \mathrm{FFQ}, \\
\text { administered at mid } \\
\text { pregnancy }\end{array}$ & Khoury's score [74] & Preterm delivery & $\begin{array}{l}\text { No association with } \\
\text { reduced risk of preterm } \\
\text { birth }\end{array}$ \\
\hline
\end{tabular}

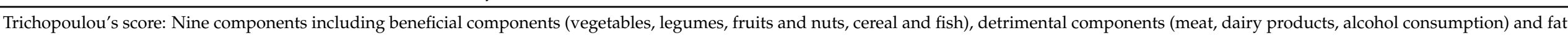

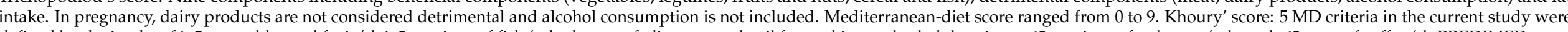

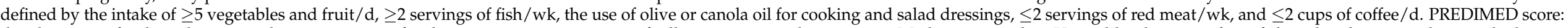

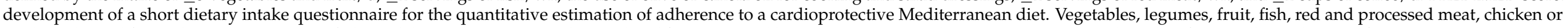

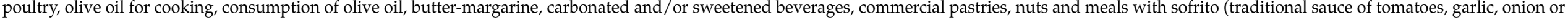

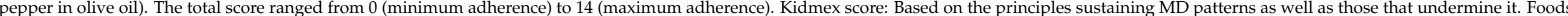

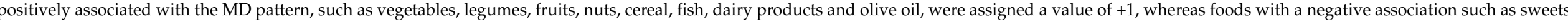
and fast foods were assigned a value of -1 . The score ranged from 0 to 12 . 
To conclude, two recent systematic reviews of literature reported growing evidence of the potential benefits of the MD diet for child development, but other randomized trials are needed to confirm these results $[80,98]$. Moreover, the strength of the association varied in the different studies, which can be affected by high heterogeneity related to the methodology used for the MD assessment. The number of food items included in the FFQ, the way of administration and the calculation of consumed foods may explain some differences between results. Another confounding factor is the period of pregnancy considered for evaluation of MD adherence [98].

\subsection{HEI, AHEI and AHEI-P Scores}

Several studies have examined birth outcome associations with these dietary indices (see Table 4). In a Spanish cohort, Rodriguez-Bernal et al. found that increasing quintiles of the AHEI-P score were associated with higher birth weight and length [99]. However, the results remain inconsistent, with several studies reporting no association between maternal AHEI-P or AHEI-2010 scores and anthropometry measurements at birth [75,100,101]. Other studies reported that low maternal HEI-2010 scores were associated with offspring adiposity and risk of being large for gestational age (LGA) [102,103]. Most of the studies of maternal diet quality during pregnancy used previous versions of HEI scores, while another study reported a lower risk of LBW with a high adherence to the HEI-2015 [104]. Variations in the dietary assessment, as some of them were updated for pregnancy and participant characteristics, are the main contribution to the discordance in the results. However, higher adherence to these indices have been strongly linked to a greater dietary variety and consumption of essential nutrients that may lead to a favourable cardiometabolic profile in pregnant women [103]. 
Table 4. Individual studies on the associations between maternal dietary quality determined by the Healthy Eating Index and birth outcomes.

\begin{tabular}{|c|c|c|c|c|c|c|c|}
\hline First Author, Year & Country or Setting & Study Design & Population & $\begin{array}{l}\text { Dietary Assessment Method and } \\
\text { Period }\end{array}$ & $\begin{array}{l}\text { Assessment of Adherence to the } \\
\text { Diet }\end{array}$ & Birth Outcomes & Key Findings \\
\hline $\begin{array}{l}\text { Zhu et al., } 2019 \\
\text { [103] }\end{array}$ & $\begin{array}{l}\text { United States, } \\
\text { 2014-2017 }\end{array}$ & $\begin{array}{l}\text { Pregnancy } \\
\text { Environment and } \\
\text { Lifestyle Study: A } \\
\text { prospective cohort }\end{array}$ & $\begin{array}{l}2269 \\
\text { multi-racial/ethnic } \\
\text { women }\end{array}$ & $\begin{array}{l}\text { FFQ during early pregnancy } \\
\text { (10-13 weeks) that collected } \\
\text { information on habitual dietary } \\
\text { intake during the previous } 3 \\
\text { months. }\end{array}$ & $\begin{array}{l}\text { HEI-2010 [64] } \\
\text { Exclusion of alcohol consumption }\end{array}$ & $\begin{array}{l}\text { Birthweight z-score, } \\
\text { large- and } \\
\text { small-for-gestational age }\end{array}$ & $\begin{array}{l}79 \% \text { of pregnant women did not adhere } \\
\text { to the Dietary Guidelines for Americans. } \\
\text { Poor diet quality in pregnancy was } \\
\text { associated with higher birthweight and } \\
\text { increased risk of LGA independent of } \\
\text { maternal obesity and other covariates }\end{array}$ \\
\hline $\begin{array}{l}\text { Navarro et al., } 2019 \\
{[\text { [104] }}\end{array}$ & Ireland, 2001-2003 & $\begin{array}{l}\text { Lifeways cross } \\
\text { generation cohort } \\
\text { study: prospective } \\
\text { family study }\end{array}$ & $\begin{array}{l}1082 \text { families at } \\
\text { birth }\end{array}$ & $\begin{array}{l}\text { Semi quantitative FFQ during the } \\
\text { first trimester of pregnancy }\end{array}$ & The HEI-2015 [57] & $\begin{array}{l}\text { Birth weight, } \\
\text { macrosomia, premature } \\
\text { birth }\end{array}$ & $\begin{array}{l}\text { Higher scores on the maternal HEI were } \\
\text { associated with lower risk of low birth } \\
\text { weight. Similar associations were found } \\
\text { for maternal grandmothers with higher } \\
\text { HEI scores, but a slightly risk of } \\
\text { macrosomia was observed }\end{array}$ \\
\hline $\begin{array}{l}\text { Chia et al., } 2018 \\
{[105]}\end{array}$ & $\begin{array}{l}\text { Singapore, } \\
\text { 2009-2010 }\end{array}$ & $\begin{array}{l}\text { The GUSTO Study, a } \\
\text { prospective } \\
\text { mother-offspring } \\
\text { cohort }\end{array}$ & $\begin{array}{l}1051 \text { pregnant } \\
\text { women }\end{array}$ & $\begin{array}{l}\text { 24-h recalls at } 26-28 \text { weeks of } \\
\text { gestation }\end{array}$ & $\begin{array}{l}\text { They used the HEI-SGP }(11 \\
\text { components with a maximum } \\
\text { possible raw score of } 90)^{*}\end{array}$ & $\begin{array}{l}\text { Preterm birth, offspring } \\
\text { birth size, and adiposity }\end{array}$ & $\begin{array}{l}\text { Higher maternal diet quality during } \\
\text { pregnancy was associated with longer } \\
\text { birth length and lower neonatal adiposity } \\
\text { No associations with birth weight or } \\
\text { preterm birth }\end{array}$ \\
\hline $\begin{array}{l}\text { Badon et al., } 2017 \\
\text { [100] }\end{array}$ & $\begin{array}{l}\text { United States, } \\
\text { 1996-2008 }\end{array}$ & $\begin{array}{l}\text { Omega study, a } \\
\text { prospective } \\
\text { pregnancy cohort }\end{array}$ & $\begin{array}{l}2924 \text { women with } \\
\text { singleton live births }\end{array}$ & $\begin{array}{c}\text { Self-administered } \\
\text { semi-quantitative FFQ, diet over } \\
\text { the last } 3 \text { months }\end{array}$ & $\begin{array}{c}\text { AHEI-2010 [65] } \\
\text { Alcohol consumption was not } \\
\text { included }\end{array}$ & $\begin{array}{l}\text { Birthweight, large- and } \\
\text { small-for-gestational age }\end{array}$ & $\begin{array}{l}\text { No associations were found with birth } \\
\text { anthropometry }\end{array}$ \\
\hline $\begin{array}{l}\text { Shapiro et al., } 2016 \\
\text { [102] }\end{array}$ & United States, 2014 & $\begin{array}{l}\text { The Healthy Start } \\
\text { cohort, a pre-birth } \\
\text { observational cohort }\end{array}$ & $\begin{array}{l}1079 \text { singleton } \\
\text { mother-offspring } \\
\text { pairs, without prior } \\
\text { medical history }\end{array}$ & $\begin{array}{l}\text { Self-Administered 24-h dietary } \\
\text { recalls during pregnancy }\end{array}$ & $\begin{array}{l}\text { HEI-2010 [64] } \\
\text { Exclusion of alcohol consumption }\end{array}$ & Neonatal adiposity & $\begin{array}{c}\text { Having an HEI-2010 score } \leq 57 \text { (poorer } \\
\text { diet quality) was significantly associated } \\
\text { with higher \%fat mass }\end{array}$ \\
\hline $\begin{array}{l}\text { Poon et al., } 2013 \\
\text { [101] }\end{array}$ & US, 2005-2007 & $\begin{array}{l}\text { The Infant Feeding } \\
\text { Practices Study II, a } \\
\text { prospective cohort } \\
\text { study }\end{array}$ & $\begin{array}{l}830 \text { women } \\
\text { included for } \\
\text { analyses after } \\
\text { exclusion of women } \\
\text { with diabetes }\end{array}$ & $\begin{array}{l}\text { Self-completed Diet History } \\
\text { Questionnaire during the third } \\
\text { trimester that reflects dietary } \\
\text { intake between } 28 \text { and } 36 \text { weeks } \\
\text { of gestation }\end{array}$ & $\begin{array}{l}\text { Alternative Healthy Eating Index for } \\
\text { Pregnancy (AHEI-P) updated from } \\
\text { the updated AHEI-2010 alcohol was } \\
\text { excluded, while calcium, folate, and } \\
\text { iron were added to the scoring } \\
\text { method }\end{array}$ & $\begin{array}{l}\text { Birthweight z-scores and } \\
\text { weight-for-length } \\
\text { z-scores }\end{array}$ & $\begin{array}{l}\text { Maternal diet quality was not associated } \\
\text { with birth anthropometry }\end{array}$ \\
\hline $\begin{array}{l}\text { Rodriguez-Bernal } \\
\text { et al., 2010 } \\
\text { [99] }\end{array}$ & $\begin{array}{l}\text { Spain, } 2004 \\
2005\end{array}$ & $\begin{array}{l}\text { The Valencia birth } \\
\text { cohort-A subproject } \\
\text { of the INMA study }\end{array}$ & $\begin{array}{l}787 \text { women and } \\
\text { their newborns }\end{array}$ & $\begin{array}{l}\mathrm{FFQ} \text {, administered by trained } \\
\text { interviewers during the first } \\
\text { trimester of pregnancy }\end{array}$ & $\begin{array}{l}\text { AHEI adapted for pregnancy ** } \\
\text { To make the index more appropriate } \\
\text { for the pregnant population, they } \\
\text { excluded the alcohol intake and } \\
\text { long-term multivitamin use. They } \\
\text { added folate, iron, and calcium } \\
\text { intakes [106] }\end{array}$ & $\begin{array}{l}\text { Birth weight, birth } \\
\text { length, and head } \\
\text { circumference at birth }\end{array}$ & $\begin{array}{l}\text { Newborns of women in the fourth } \\
\text { quintile were heavier and longer than } \\
\text { those in the lowest quintile. } \\
\text { Decreased risk of foetal growth-restricted } \\
\text { infant for weight in women with the } \\
\text { highest AHEI. }\end{array}$ \\
\hline $\begin{array}{l}\text { Rifas-Shiman et al., } \\
2009 \text { [75] }\end{array}$ & US, 1999-2002 & $\begin{array}{l}\text { Project Viva: } \\
\text { prospective cohort } \\
\text { study }\end{array}$ & $\begin{array}{l}1777 \text { women with } \\
\text { singleton live births }\end{array}$ & $\begin{array}{c}\text { Self-administered } \\
\text { semi-quantitative FFQ assessing } \\
\text { the woman's diet during early } \\
\text { pregnancy and the second } \\
\text { trimester }\end{array}$ & $\begin{array}{l}\text { AHEI-P: Exclusion of alcohol, nuts } \\
\text { and soy protein component and } \\
\text { inclusion of tofu or soybeans in the } \\
\text { vegetable component, } \\
\text { folate, iron, and calcium }\end{array}$ & $\begin{array}{l}\text { Birth weight for } \\
\text { gestational age } \\
\text { categories: small and } \\
\text { large for gestational age }\end{array}$ & No associations with foetal growth \\
\hline
\end{tabular}

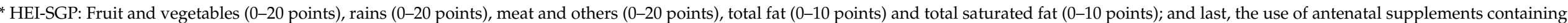

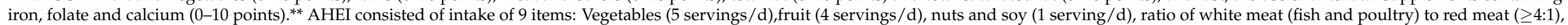
cereal fibre $(15 \mathrm{~g} / \mathrm{d})$, trans fat $(\leq 0.5 \%$ of energy), ratio of polyunsaturated to saturated fat $(\geq 1)$, moderate alcohol intake $(0.5-1.5$ servings $/ \mathrm{d})$ and long-term multivitamin use ( $\geq 5 \mathrm{y}$ of continuous use). 


\subsection{DASH}

A systematic review and meta-analysis of RCTs provides evidence that the DASH diet could play a role in glycaemic control and improve gestational outcomes in women with cardiometabolic disorders such as GDM, hypertension or obesity [107]. Among the studies included, one revealed that adherence to the DASH diet for 4 weeks among pregnant women with GDM was associated with improved fasting glucose profile and reduce the use of insulin therapy. Mean birthweight, head circumference and ponderal index of infants born in the intervention group were significantly lower compared with those born to mothers in the control arm [78]. Other observational and RCTs report that adherence to the DASH diet in women with risk factors (obesity, hypertension) was associated with lower birthweight or birth length, a lower risk of prematurity or having a LGA infant $[82,108]$. Inversely, another RCT conducted in a group of overweight and obese women failed to demonstrate improved birth outcomes with a DASH diet, even when a reduction of gestational weight gain was observed [109]. A description of the few studies included is shown in Table 5. The published literature on the relationship of the DASH diet with birth outcomes remains inconsistent. Differences between studies regarding the diagnosis of GDM, hypertension or obesity might explain fundamental physiological differences between the included women [110]. Future studies including more generalisable populations are needed to ascertain the effect of the DASH diet [107]. A recent meta-analysis of the ALPHABET European project, conducted in a general population of pregnant women, has shown that a higher pregnancy DASH score was associated with higher birth weight $[\beta(95 \% \mathrm{CI})=18.5(5.7,31.3) \mathrm{g}$ per 1-SD higher DASH score] and head circumference $[0.03(0.01,0.06) \mathrm{cm}]$, as well as longer birth length $[0.05(0.01,0.10) \mathrm{cm}]$, and lower risk of delivering SGA $[0.87(0.82,0.94)]$ infants [87]. 
Table 5. Individual studies on the associations between maternal DASH scores and birth outcomes.

\begin{tabular}{|c|c|c|c|c|c|c|c|}
\hline First Author, Year & Country or Setting & Study Design & Population & $\begin{array}{l}\text { Dietary Assessment } \\
\text { Method/Intervention and } \\
\text { Period }\end{array}$ & Assessment of Adherence to the Diet & Birth Outcomes & Key Findings \\
\hline Jiang et al., 2019 [82] & China, 2015-2017 & $\begin{array}{l}\text { Randomized controlled } \\
\text { Trial }\end{array}$ & $\begin{array}{l}85 \text { pregnant women } \\
\text { diagnosed with } \\
\text { gestational or chronic } \\
\text { hypertension }\end{array}$ & $\begin{array}{l}\text { Intervention: DASH diet } \\
\text { vs. control (usual diet), } \\
\text { randomly assigned at } 12 \\
\text { weeks }\end{array}$ & $\begin{array}{l}\text { The Dietary Approaches to Stop } \\
\text { Hypertension (DASH) diet was modified } \\
\text { to accommodate specific needs of } \\
\text { pregnancies. The diet was similar to the } \\
\text { control diet in terms of macronutrients } \\
(50-60 \% \text { carbohydrate, } 20-25 \% \text { fat and } \\
20-25 \% \text { protein); however, it was rich in } \\
\text { fruits, vegetables, whole grains and } \\
\text { low-fat dairy products; low in saturated } \\
\text { fats, cholesterol and sweets. The amount } \\
\text { of salt intake was } 4 \mathrm{~g} / \mathrm{d} \text {. }\end{array}$ & $\begin{array}{l}\text { Prematurity, birth weight, } \\
\text { body length and Apgar } \\
\text { score }\end{array}$ & $\begin{array}{l}\text { Beneficial effects on the } \\
\text { incidence of prematurity, } \\
\text { low birth weight and } \\
\text { infant body length }\end{array}$ \\
\hline $\begin{array}{c}\text { Van Horn et al., } 2018 \\
\text { [109] }\end{array}$ & USA, 2012-2015 & $\begin{array}{l}\text { Maternal Offspring } \\
\text { Metabolics Family } \\
\text { Intervention Trial } \\
\text { (MOMFIT): Randomized } \\
\text { controlled Trial }\end{array}$ & $\begin{array}{l}281 \text { overweight/obese } \\
\text { women randomized at } \\
16 \text {-week gestation }\end{array}$ & $\begin{array}{l}\text { Intervention DASH diet vs. } \\
\text { usual care. The two groups } \\
\text { received the 2008 Physical } \\
\text { Activity Guidelines for } \\
\text { Americans.Second and } \\
\text { third trimester of } \\
\text { pregnancy }\end{array}$ & $\begin{array}{l}\text { Minor modifications to the DASH diet, } \\
\text { called MAMA-DASH, were calorically } \\
\text { suited to the restricted weight gain } \\
\text { recommendations, and followed } \\
\text { nutrition guidelines for pregnant women, } \\
\text { including avoidance of fish considered } \\
\text { higher in mercury, inclusion of } \\
\text { calcium-rich, vitamin D-enriched dairy, } \\
\text { or calcium-fortified non-dairy products }\end{array}$ & Newborn anthropometry & $\begin{array}{c}\text { No significant differences } \\
\text { in birth anthropometric } \\
\text { measurements, percentage } \\
\text { body fat }\end{array}$ \\
\hline Fulay et al., 2018 [110] & USA, 1999-2002 & $\begin{array}{l}\text { Project VIVA: } \\
\text { longitudinal cohort } \\
\text { study }\end{array}$ & $\begin{array}{l}1760 \text { women included } \\
\text { with a singleton } \\
\text { pregnancy }\end{array}$ & $\begin{array}{l}\text { Semi-quantitative } F F Q \text {, at } \\
\text { study enrolment in the first } \\
\text { trimester of pregnancy }\end{array}$ & $\begin{array}{l}\text { Calculation of two dietary patterns: } \\
\text { DASH diet and } \\
\text { DASH OMNI pattern, which is based on } \\
\text { the original DASH diet supplemented by } \\
\text { higher unsaturated fat intake }\end{array}$ & $\begin{array}{l}\text { Birth size and preterm } \\
\text { delivery }\end{array}$ & $\begin{array}{l}\text { Adherence to neither } \\
\text { DASH or DASH OMNI } \\
\text { diet during early } \\
\text { pregnancy were associated } \\
\text { with prematurity or birth } \\
\text { anthropometry }\end{array}$ \\
\hline Vesco et al., 2015 [108] & USA, 2009-2011 & $\begin{array}{l}\text { Randomized controlled } \\
\text { Trial }\end{array}$ & $\begin{array}{l}114 \text { obese women } \\
\text { randomized between } \\
7-21 \text { weeks' gestation }\end{array}$ & $\begin{array}{l}\text { DASH diet with least } 30 \\
\text { min of moderate physical } \\
\text { activity vs. control group } \\
\text { who received one time } \\
\text { advice session without any } \\
\text { particular focus on DASH } \\
\text { diet or weight } \\
\text { management }\end{array}$ & $\begin{array}{l}\text { Energy reduced eating plan, based on } \\
\text { DASH dietary pattern without sodium } \\
\text { restriction. }\end{array}$ & $\begin{array}{c}\text { Small and large for } \\
\text { gestational age, } \\
\text { weight-for-gestational-age } \\
\mathrm{z} \text {-score, macrosomia }\end{array}$ & $\begin{array}{c}\text { Intervention group had } \\
\text { lower risk of having LGA } \\
\text { infant }\end{array}$ \\
\hline $\begin{array}{c}\text { Martin et al., } 2015 \\
\text { [111] }\end{array}$ & USA, 1995-2000 & $\begin{array}{l}\text { PIN (Pregnancy, } \\
\text { Infection, and Nutrition): } \\
\text { Prospective cohort study }\end{array}$ & $\begin{array}{l}3143 \text { pregnant women } \\
\text { included }\end{array}$ & $\begin{array}{l}\text { Self-administered FFQ } \\
26-29 \text { weeks of gestation }\end{array}$ & $\begin{array}{l}\text { DASH diet was characterized positively } \\
\text { by intake of fruits, vegetables, nuts and } \\
\text { legumes, low-fat dairy and whole grains. } \\
\text { Sodium, red and processed meats, and } \\
\text { sweetened beverage were } \\
\text { reversed-scored }\end{array}$ & Premature birth & $\begin{array}{l}\text { Greater adherence to the } \\
\text { DASH diet is associated } \\
\text { with decreased odds of } \\
\text { prematurity compared } \\
\text { with women in the lowest } \\
\text { quartile }\end{array}$ \\
\hline Asemi et al., 2014 [78] & Iran, 2013 & $\begin{array}{c}\text { Randomized controlled } \\
\text { Trial }\end{array}$ & $\begin{array}{c}52 \text { women diagnosed } \\
\text { with gestational diabetes } \\
\text { mellitus }\end{array}$ & $\begin{array}{l}\text { Intervention: DASH diet } \\
\quad \text { for } 4 \text { weeks during } \\
\text { pregnancy vs. control diet } \\
\text { with similar calorie content } \\
\text { and protein composition }\end{array}$ & $\begin{array}{l}\text { DASH diet was rich in fruits, vegetables, } \\
\text { whole grains and low-fat dairy products, } \\
\text { and low in saturated fats, cholesterol, } \\
\text { refined grains and sweets. The amount } \\
\text { ofsodium intake was } 2400 \mathrm{mg} \text { per day }\end{array}$ & $\begin{array}{l}\text { Birthweight, Birth length, } \\
\text { Head circumference at } \\
\text { birth, Ponderal Index, } \\
\text { Apgar score, Macrosomia, } \\
\text { Polyhydramnios, } \\
\text { Gestational age }\end{array}$ & $\begin{array}{l}\text { Lower birth weight, head } \\
\text { circumference and } \\
\text { ponderal Index in the } \\
\text { intervention group }\end{array}$ \\
\hline
\end{tabular}




\subsection{GI/GL}

A recent meta-analysis of 11 randomized trials including 1985 women has shown that compared with control diets, a low GI diet significantly reduced fasting and 2-h postprandial blood glucose levels and proportion of LGA infants [36]. However, some of the RCTs were conducted mostly in high-risk populations (with a history of gestational diabetes or previous macrosomic infant) and differed in terms of study design, which may contribute to heterogeneity among the studies and may partly explain the inconsistent results [81,112] (Table 6). The ROLO study is an RCT of 800 secundigravida women who had previously given birth to a macrosomic baby $(>4 \mathrm{~kg}$ ), randomised to low GI dietary advice vs. usual antenatal care, which did not involve dietary advice [81]. No differences between groups were reported in birth weight or 6-month offspring adiposity [81,113], whereas another RCT conducted in women with diabetes showed a trend of lower birth weight after a low GI carbohydrate intervention compared to all types of carbohydrates [112]. Other observational studies reported controversial results between GI/GL and birth outcomes $[35,38,40,83]$. A prospective cohort in Ireland evaluated the associations between maternal GI, GL, insulinemic index/load (II, IL) and offspring birth outcomes. Dietary II and IL may play an important role in blood glucose regulation [38]. No associations between glycaemic or insulinemic indices during early pregnancy with birth weight, BMI at birth or gestational age were observed [38]. In summary, some studies indicate reduced risk of adverse neonatal outcomes following a low-GI dietary intervention. However, the evidence is limited, and results should be interpreted with caution because of the evidence of heterogeneity across studies. 
Table 6. Individual studies on the associations between maternal glycaemic index and birth outcomes.

\begin{tabular}{|c|c|c|c|c|c|c|c|}
\hline First Author, Year & Country or Setting & Study Design & Population & $\begin{array}{c}\text { Dietary Assessment } \\
\text { Method/Intervention and } \\
\text { Period }\end{array}$ & Assessment of Adherence to the Diet & Birth Outcomes & Key Findings \\
\hline $\begin{array}{c}\text { Wahab et al., } 2020 \\
\text { [35] }\end{array}$ & $\begin{array}{l}\text { Netherlands, } \\
\text { 2002-2006 }\end{array}$ & $\begin{array}{l}\text { Generation R: } \\
\text { Population-based } \\
\text { prospective birth cohort } \\
\text { study }\end{array}$ & $\begin{array}{l}3471 \text { pregnant women } \\
\text { without any medical } \\
\text { conditions }\end{array}$ & $\begin{array}{l}\text { Semi-quantitative FFQ in } \\
\text { first trimester }\end{array}$ & $\begin{array}{l}\text { GI values were obtained from the } \\
\text { glycaemic index database on the Dutch } \\
\text { diet published by the Medical Research } \\
\text { Council Human Nutrition Research } \\
\text { Calculation of the GI and GL }\end{array}$ & $\begin{array}{c}\text { Foetal growth in mid and } \\
\text { late pregnancy } \\
\text { Birth weight, risk of SGA, } \\
\text { LGA, } \\
\text { Preterm birth }\end{array}$ & $\begin{array}{l}\text { Higher maternal early } \\
\text { pregnancy GL was } \\
\text { associated with a higher } \\
\text { foetal abdominal } \\
\text { circumference and } \\
\text { estimated foetal weight in } \\
\text { late pregnancy. } \\
\text { Higher maternal early } \\
\text { pregnancy GI was } \\
\text { associated with a lower } \\
\text { risk of a } \\
\text { large-for-gestational-age } \\
\text { infant }\end{array}$ \\
\hline Chen et al., 2019 [38] & Ireland, 2001 & $\begin{array}{l}\text { Lifeways study: } \\
\text { Prospective cohort study }\end{array}$ & $\begin{array}{l}842 \text { mother-child pairs } \\
\text { with singleton live births }\end{array}$ & $\begin{array}{l}\text { Semi-quantitative } F F Q \\
\text { self-completed at the first } \\
12-16 \text { weeks of pregnancy }\end{array}$ & $\begin{array}{l}\text { To calculate dietary GI and GL, food } \\
\text { items listed in the FFQ were matched to } \\
\text { corresponding food items in databases } \\
\text { with published GI values. Average } \\
\text { participant GL was derived by summing } \\
\text { the food intake frequency-weighted GL } \\
\text { for all food items. The average dietary GI } \\
\text { of participants was calculated by } \\
\text { dividing their GL by their total available } \\
\text { carbohydrate intake, then multiplying by } \\
100 .\end{array}$ & $\begin{array}{l}\text { Birth weight, macrosomia, } \\
\text { gestational age }\end{array}$ & $\begin{array}{l}\text { Neither glycaemic nor } \\
\text { insulinemic responses to } \\
\text { diet during early } \\
\text { pregnancy appear to be } \\
\text { associated with offspring } \\
\text { birth weight, gestational } \\
\text { age, BMI at birth }\end{array}$ \\
\hline Gomes et al., 2019 [40] & Brazil, 2012-2013 & Cohort study & 259 women & $\begin{array}{l}\text { Two 24-h dietary recalls in } \\
\text { each gestational trimester }\end{array}$ & $\begin{array}{l}\text { The dietary GI and GL values were } \\
\text { obtained from the Nutrition Data System } \\
\text { for Research software.Calculated for the } \\
\text { second and third trimester }\end{array}$ & $\begin{array}{l}\text { Birth weight z-score } \\
\text { calculated using the e } \\
\text { Intergrowth-21st Project }\end{array}$ & $\begin{array}{l}\text { No association between } \\
\text { GI/GL and birth weight } \\
\text { were observed }\end{array}$ \\
\hline $\begin{array}{c}\text { Horan et al., } 2016 \\
\text { [113] }\end{array}$ & Ireland, 2007-2011 & $\begin{array}{l}\text { The ROLO study: } \\
\text { Randomized controlled } \\
\text { trial }\end{array}$ & $\begin{array}{c}280 \text { mother-infant pairs. } \\
\text { Participants were } \\
\text { secundigravida women } \\
\text { with a previous } \\
\text { macrosomic baby }(>4 \\
\mathrm{kg} \text { ). }\end{array}$ & $\begin{array}{l}\text { Low GI dietary advice vs. } \\
\text { usual antenatal care, which } \\
\text { did not involve dietary } \\
\text { advice. } \\
\text { 3-day food diaries were } \\
\text { completed at each } \\
\text { trimester of pregnancy }\end{array}$ & $\begin{array}{l}\text { GI values were determined using the } \\
2008 \text { International Tables of GI values } \\
\text { and other recently published GI values }\end{array}$ & $\begin{array}{c}\text { Offspring adiposity at } 6 \\
\text { months }\end{array}$ & $\begin{array}{c}\text { No difference was found in } \\
6 \text { months infant adiposity } \\
\text { between control and } \\
\text { intervention groupsbut } \\
\text { maternal trimester } 3 \mathrm{GI} \\
\text { was positively associated } \\
\text { with } 6 \text { months old triceps } \\
\text { skinfold thickness for age } \\
\text { z-score and biceps skinfold } \\
\text { thickness }\end{array}$ \\
\hline
\end{tabular}


Table 6. Cont.

\begin{tabular}{|c|c|c|c|c|c|c|c|}
\hline First Author, Year & Country or Setting & Study Design & Population & $\begin{array}{l}\text { Dietary Assessment } \\
\text { Method/Intervention and } \\
\text { Period }\end{array}$ & Assessment of Adherence to the Diet & Birth Outcomes & Key Findings \\
\hline Moses et al., 2014 [114] & Australia, 2010 & $\begin{array}{l}\text { PREGGIO (Pregnancy } \\
\text { and Glycaemic Index } \\
\text { outcomes): A } \\
\text { randomized controlled } \\
\text { trial }\end{array}$ & $\begin{array}{l}576 \text { women without any } \\
\text { medical conditions }\end{array}$ & $\begin{array}{l}\text { Low GI dietary advice at } \\
\text { the first antenatal visit vs. } \\
\text { healthy eating diet. } \\
\text { Participants were provided } \\
\text { with } 1 \text { of } 2 \text { sets of booklets } \\
\text { (depending on their } \\
\text { allocation) that included } \\
\text { information on the choices } \\
\text { for and serving sizes of } \\
\text { carbohydrate-rich foods. } \\
\text { No intended difference in } \\
\text { the macronutrient } \\
\text { distribution in diets }\end{array}$ & $\begin{array}{l}\text { Database incorporated Australian } \\
\text { food-composition tables and published } \\
\text { GI valuesThe dietary GI was calculated } \\
\text { as the weighted sum of the GI of all } \\
\text { carbohydrate (CHO) foods in the diet, } \\
\text { with the weighting proportional to the } \\
\text { contribution of each food to total CHO } \\
\text { intake. Glycaemic load is the product of } \\
\text { the GI and amount of CHO. }\end{array}$ & $\begin{array}{l}\text { Birth anthropometry and } \\
\text { ponderal index }\end{array}$ & $\begin{array}{l}\text { No significant differences } \\
\text { in foetal birth weight, } \\
\text { length, and ponderal index } \\
\text { between the two groups. } \\
\text { GL was the only predictor } \\
\text { of birth percentile and } \\
\text { ponderal index. }\end{array}$ \\
\hline $\begin{array}{l}\text { Knudsen et al., } 2013 \\
\text { [83] }\end{array}$ & Denmark, 1996-2002 & $\begin{array}{l}\text { Danish national birth } \\
\text { cohort: Prospective birth } \\
\text { cohort study }\end{array}$ & $\begin{array}{l}41,782 \text { first trimester } \\
\text { pregnant women }\end{array}$ & $\begin{array}{l}\text { Self-administered FFQ in } \\
\text { week } 25 \text { of gestation }\end{array}$ & $\begin{array}{l}\text { Values of the GI were extracted from } \\
\text { published data and were incorporated } \\
\text { into the dietary database. } \\
\text { Calculation of the GI and GL }\end{array}$ & $\begin{array}{l}\text { Birth weight, SGA or LGA } \\
\text { risks }\end{array}$ & $\begin{array}{l}\text { Mean of birthweight was } \\
\text { higher in the highest GL } \\
\text { quintile compared to the } \\
\text { lowest and increased risk } \\
\text { of LGA was observed in } \\
\text { the highest GL quintile. }\end{array}$ \\
\hline Walsh et al., 2012 [81] & Ireland, 2007-2011 & $\begin{array}{l}\text { The ROLO study: } \\
\text { Randomized controlled } \\
\text { trial }\end{array}$ & $\begin{array}{c}800 \text { secundigravida } \\
\text { women with a previous } \\
\text { macrosomic baby }(>4 \\
\mathrm{kg}) \text {. }\end{array}$ & $\begin{array}{l}\text { Low GI diet from } 14 \text { weeks } \\
\text { gestation to delivery vs. no } \\
\text { dietary intervention. } \\
\text { Research dietitian met the } \\
\text { patients at } 28 \text { and } 34 \text { weeks' } \\
\text { gestation. }\end{array}$ & $\begin{array}{l}\text { Women were encouraged to choose as } \\
\text { many low GI foods as possible and to } \\
\text { exchange high GI carbohydrates for low } \\
\text { GI alternatives. Women were not advised } \\
\text { to reduce their total caloric intake. }\end{array}$ & Birth weight & $\begin{array}{l}\text { No significant difference } \\
\text { was seen between the two } \\
\text { groups in absolute birth } \\
\text { weight, birth length, head } \\
\text { circumference or ponderal } \\
\text { index at birth }\end{array}$ \\
\hline $\begin{array}{l}\text { Perichart-Perera et al., } \\
2012 \text { [112] }\end{array}$ & Mexico, 2004-2008 & $\begin{array}{l}\text { Randomized controlled } \\
\text { trial }\end{array}$ & $\begin{array}{l}107 \text { women recruited } \\
\text { with gestational diabetes } \\
\text { or pregestational type } 2 \\
\text { diabetes mellitus }\end{array}$ & $\begin{array}{c}\text { Control group }(n=61): \\
\text { women received an } \\
\text { individual food plan based } \\
\text { on CHO restriction. } \\
\text { Women in this group were } \\
\text { advised to choose any type } \\
\text { of CHO, except added } \\
\text { refined sugars. } \\
\text { Intervention group ( } n=46) \text { : } \\
\text { women were counselled to } \\
\text { eliminate all moderate and } \\
\text { high GI foods (GI }>55) \\
\text { Energy and CHO } \\
\text { prescriptions were revised } \\
\text { at every visit and changes } \\
\text { were done according to } \\
\text { weight gain }\end{array}$ & $\begin{array}{l}\text { Educational themes included the } \\
\text { importance of healthy eating with } \\
\text { diabetes, identification of CHO, } \\
\text { exchange lists and CHO counting, } \\
\text { identification of high and low GI foods, } \\
\text { healthy fats and importance of capillary } \\
\text { glucose self-monitoring. } \\
\text { Significant decrease in the GI in the } \\
\text { interventional group }\end{array}$ & $\begin{array}{l}\text { Birth anthropometry } \\
\text { measurements, } \\
\text { macrosomia, prematurity, }\end{array}$ & $\begin{array}{c}\text { A trend of lower } \\
\text { birthweight was observed } \\
\text { in the intervention group } \\
\text { without risk of SGA. } \\
\text { Higher frequency of } \\
\text { premature birth was } \\
\text { observed in the } \\
\text { intervention group. }\end{array}$ \\
\hline
\end{tabular}




\section{Maternal Dietary Metrics and Offspring Childhood Outcomes}

In line with the $\mathrm{DOHaD}$ hypothesis, maternal diet associations with offspring health may not be restricted to birth and may have longer term implications. Here we summarise the literature regarding the relationship between maternal dietary quality metrics and dietary inflammatory potential with offspring outcomes related to childhood growth and obesity. A summary of the studies and their key findings is presented in Table 7. 
Table 7. Studies investigating maternal dietary scores and long-term offspring outcomes.

\begin{tabular}{|c|c|c|c|c|c|c|c|}
\hline First Author, Year & Country/Setting & Study Design & Population & $\begin{array}{l}\text { Maternal Dietary } \\
\text { Assessment Method }\end{array}$ & $\begin{array}{l}\text { Assessment of Adherence } \\
\text { to Diet/Dietary Score }\end{array}$ & $\begin{array}{c}\text { Long-term } \\
\text { Outcome/Median Child } \\
\text { Age }\end{array}$ & Key Findings \\
\hline $\begin{array}{c}\text { Callanan et al., } 2021 \\
\text { [115] }\end{array}$ & Ireland2007-2011 & $\begin{array}{l}\text { Randomized controlled } \\
\text { trialThe ROLO study }\end{array}$ & 387 mother-child pairs & $\begin{array}{l}\text { 3-day food diary during } \\
\text { each trimester of } \\
\text { pregnancyLow GI diet } \\
\text { from 14 weeks gestation to } \\
\text { delivery vs. no dietary } \\
\text { intervention }\end{array}$ & $\begin{array}{c}\text { Low eucaloric GI diet } \\
\text { (dietary education sessions } \\
\text { with a research dietitian) } \\
\text { vs. control } \\
\text { (routine antenatal care) }\end{array}$ & $\begin{array}{l}\text { Anthropometry and child } \\
\text { adiposity at } 5 \text { years }\end{array}$ & $\begin{array}{l}\text { No significant associations were found } \\
\text { between low GI in pregnancy RCT group } \\
\text { and child weight/body composition } \\
\text { outcomes (these included weight, BMI, } \\
\text { centiles, waist-hip ratio, central } \\
\text { adiposity, total fat mass and total lean } \\
\text { mass) at } 5 \text { years follow-up. }\end{array}$ \\
\hline $\begin{array}{c}\text { Strohmaier et al., } 2020 \\
\text { [116] }\end{array}$ & USA & $\begin{array}{c}\text { Retrospective } \\
\text { observational analysis of } \\
\text { the Nurses' Health } \\
\text { Study II (NHSII) and } \\
\text { Growing Up Today } \\
\text { Study II (GUTSII) } \\
\text { cohorts. }\end{array}$ & 2729 mother-child pairs & $\begin{array}{l}\text { FFQof habitual diet within } \\
\text { last } 12 \text { months during } \\
\text { peripregnancy period }\end{array}$ & $\begin{array}{l}\text { AHEI-2010 [65], Alternate } \\
\text { Mediterranean Diet } \\
\text { (aMED) (Trichopoulou's } \\
\text { Score modified for } \\
\text { pregnancy) and DASH } \\
\text { based on } 8 \text { components } \\
\text { (fruits, vegetables, nuts } \\
\text { and legumes, low-fat dairy } \\
\text { and whole grains, sodium, } \\
\text { red and processed meat } \\
\text { and sugar-sweetened } \\
\text { beverages) }\end{array}$ & $\begin{array}{l}\text { Anthropometry- } \\
\text { overweight and obesity, } \\
12-23 \text { years }\end{array}$ & $\begin{array}{c}\text { Greater maternal adherence to aMED } \\
\text { and DASH, but not AHEI, was } \\
\text { associated with lower overweight risk in } \\
\text { the offspring (RR }(\mathrm{RR} \text { vs } \mathrm{Q1}=0.82 \text { for aMED } \\
\text { and } 0.86 \text { for DASH, } P \text { for trend }<0.05 \text { for } \\
\text { both) but none of the } 3 \text { scores remained } \\
\text { significantly associated with offspring } \\
\text { overweight or obesity risk after further } \\
\text { adjustment for maternal pre-pregnancy } \\
\text { BMI and lifestyle factors (maternal } \\
\text { smoking status and physical activity) } \\
\text { before pregnancy }\end{array}$ \\
\hline $\begin{array}{c}\text { Maslova et al., } 2019 \\
{[117]}\end{array}$ & Denmark & $\begin{array}{l}\text { Population-based cohort } \\
\text { study-Danish National } \\
\text { Birth Cohort (DNBC) }\end{array}$ & $\begin{array}{c}68,471 \text { mother-offspring } \\
\text { pairs }\end{array}$ & $\begin{array}{c}\text { 360-items } \\
\text { semi-quantitative FFQ } \\
\text { during mid-pregnancy } \\
\text { (25-week gestation) }\end{array}$ & $\begin{array}{l}\text { Reference of GI were } \\
\text { retrieved from published } \\
\text { data relevant to the time } \\
\text { period ofenrolment } \\
\text { Calculation of the GI and } \\
\text { GL per day }\end{array}$ & $\begin{array}{l}\text { Age- and sex-specific BMI } \\
z \text { scores and growth } \\
\text { velocities at } 7 \text { years }\end{array}$ & $\begin{array}{l}\text { Higher maternal GI and GL were } \\
\text { associated with an increase in the 7-year } \\
\text { BMI } z \text { score in the unadjusted analysis; } \\
\text { association was not significant in } \\
\text { adjusted analysis. Children of } \\
\text { underweight women showed a potential } \\
\text { higher risk of overweight/obesity at age } \\
7 \text { with higher maternal GI and GL, but } \\
\text { with wide confidence intervals. }\end{array}$ \\
\hline Chen et al., 2019 [38] & Ireland & $\begin{array}{l}\text { Prospective } \\
\text { cohort-Lifeways } \\
\text { Cross-Generation } \\
\text { Cohort Study }\end{array}$ & 842 mother-child pairs & $\begin{array}{l}\text { FFQduring the first 12-16 } \\
\text { weeks of pregnancy }\end{array}$ & $\begin{array}{l}\text { Food items were matched } \\
\text { to corresponding food } \\
\text { items in databases with } \\
\text { published GI values using } \\
\text { a UK database. Calculation } \\
\text { of the GI, GL, II and IL }\end{array}$ & $\begin{array}{l}\text { Children's body mass } \\
\text { index (BMI) and waist } \\
\text { circumference at } 5 \text { years }\end{array}$ & $\begin{array}{l}\text { No association was observed for scores } \\
\text { with BMI \& waist circumference z-scores } \\
\text { and childhood obesity (general and } \\
\text { central) at 5-y follow-up }\end{array}$ \\
\hline $\begin{array}{c}\text { Gonzalez-Nahm et al., } \\
2019 \text { [118] }\end{array}$ & Southwestern USA & $\begin{array}{c}\text { Prospective } \\
\text { cohort-Nurture Study }\end{array}$ & 623 mother-infant pairs & $\begin{array}{l}\text { FFQ during 2nd-3rd } \\
\text { trimester }\end{array}$ & $\begin{array}{c}\text { AHEI-2010 [65] } \\
\text { (excluding alcohol) }\end{array}$ & $\begin{array}{l}\text { Anthropometry, at birth, } 6 \\
\text { months, } 12 \text { months }\end{array}$ & $\begin{array}{l}\text { After adjustment, maternal AHEI-2010 } \\
\text { was not associated with infant adiposity } \\
\text { at birth, } 6 \text { or } 12 \text { months. }\end{array}$ \\
\hline Tahir et al., 2019 [119] & USA & $\begin{array}{c}\text { Prospective } \\
\text { cohort-MILK Study }\end{array}$ & 354 mother-infant pairs & $\begin{array}{l}\text { FFQ3rd trimester, } 1 \text { month } \\
\text { postpartum, } 3 \text { months } \\
\text { postpartum }\end{array}$ & HEI-2015 [57] & $\begin{array}{l}\text { Anthropometry at birth, } 1 \\
\text { month, } 3 \text { months and } 6 \\
\text { months }\end{array}$ & $\begin{array}{c}\text { A 10-unit increase in HEI-2015 total } \\
\text { scores during pregnancy was associated } \\
\text { with an approximately } 0.6 \% \text { lower infant } \\
\text { body fat } \% \text { at six months ( } \beta=-0.58, p= \\
0.05) .\end{array}$ \\
\hline
\end{tabular}


Table 7. Cont

\begin{tabular}{|c|c|c|c|c|c|c|c|}
\hline First Author, Year & Country/Setting & Study Design & Population & $\begin{array}{l}\text { Maternal Dietary } \\
\text { Assessment Method }\end{array}$ & $\begin{array}{l}\text { Assessment of Adherence } \\
\text { to Diet/Dietary Score }\end{array}$ & $\begin{array}{c}\text { Long-term } \\
\text { Outcome/Median Child } \\
\text { Age }\end{array}$ & Key Findings \\
\hline $\begin{array}{l}\text { Navarro et al., } 2019 \\
{[24]}\end{array}$ & Ireland & $\begin{array}{l}\text { Prospective } \\
\text { cohort-Lifeways } \\
\text { Cross-Generation } \\
\text { Cohort Study }\end{array}$ & $\begin{array}{l}1082 \text { child-mother pairs; } \\
585 \text { children }\end{array}$ & $\begin{array}{l}\text { FFQduring the first12-16 } \\
\text { weeks of pregnancy }\end{array}$ & $\begin{array}{l}\text { E-DII (as described in } \\
\text { Table 2) }\end{array}$ & $\begin{array}{l}\text { Anthropometric Outcomes } \\
5 \text { years and } 9 \text { years }\end{array}$ & $\begin{array}{c}\text { No associations were found between } \\
\text { maternal E-DII scores and offspring } \\
\text { overweight and/or obesity at } 5 \text { and } 9 \\
\text { years }\end{array}$ \\
\hline $\begin{array}{l}\text { Navarro et al., } 2019 \\
\text { [104] }\end{array}$ & Ireland & $\begin{array}{l}\text { Prospective } \\
\text { cohort-Lifeways } \\
\text { Cross-Generation } \\
\text { Cohort Study }\end{array}$ & $\begin{array}{l}1082 \text { child-mother pairs; } \\
585 \text { children }\end{array}$ & $\begin{array}{l}\text { FFQduring the first 12-16 } \\
\text { weeks of pregnancy }\end{array}$ & HEI-2015 [57] & $\begin{array}{l}\text { Anthropometric Outcomes } \\
\text { at } 5 \text { years }\end{array}$ & $\begin{array}{l}\text { No associations between maternal HEI } \\
\text { scores and childhood overweight or } \\
\text { obesity; higher paternal HEI scores were } \\
\text { associated with lower odds ratios of } \\
\text { childhood obesity at } 5 \text { years old }\end{array}$ \\
\hline Sen et al., 2018 [84] & USA & $\begin{array}{l}\text { Longitudinal } \\
\text { cohort-Project Viva }\end{array}$ & 922 mother-child pairs & $\begin{array}{l}\text { Validated semi } \\
\text { quantitative FFQ } \\
\text { completed between } \\
\text { 10-28-week gestation }\end{array}$ & $\begin{array}{l}\text { DII calculated based on } \\
28 \text { dietary parameters: } \\
\text { energy, carbohydrate, } \\
\text { protein, fat, alcohol, fibre, } \\
\text { cholesterol, SFAs, MUFAs, } \\
\text { PUFAs, n-3 and n-6 FAs, } \\
\text { trans-fat, niacin, thiamin, } \\
\text { riboflavin, vitamin B-12, } \\
\text { vitamin B-6, iron, } \\
\text { magnesium, zinc, } \\
\text { selenium, vitamin A, } \\
\text { vitamin C, vitamin D, } \\
\text { vitamin E, folic acid, and } \\
\beta \text {-carotene. }\end{array}$ & $\begin{array}{c}\text { Anthropometric Outcomes } \\
\text { (range 6-10 years, median } \\
7.7 \text { years) }\end{array}$ & $\begin{array}{l}\text { Higher maternal DII in pregnancy was } \\
\text { directly associated with offspring size in } \\
\text { mid-childhood, including BMI z-score, } \\
\text { fat-free mass index and waist } \\
\text { circumference as well as more direct } \\
\text { measures of adiposity and } \\
\text { dysmetabolism, including fat mass index, } \\
\text { trunk fat mass index and fasting insulin }\end{array}$ \\
\hline $\begin{array}{c}\text { Chatzi et al., } 2017 \\
\text { [120] }\end{array}$ & USA and Greece & $\begin{array}{l}\text { Population-based } \\
\text { prospective cohorts }\end{array}$ & 1566 mother-child pairs & FFQ during 1st trimester & $\begin{array}{l}\text { MDS ranging from } 0-9 \text {, } \\
\text { Trichopolous score } \\
\text { modified based } \\
\text { on recommendations for } \\
\text { pregnant women [71] }\end{array}$ & $\begin{array}{l}\text { Child adiposity, blood } \\
\text { pressure and } \\
\text { cardiometabolic } \\
\text { parameters } \\
\text { Mid-childhood (median } 7.7 \\
\text { years USA; median } 4.2 \\
\text { years Greece) }\end{array}$ & $\begin{array}{c}\text { For each 3-pt increment in the MDS: } \\
\text { offspring BMI } z \text {-score was lower by } 0.14 \\
\text { units }(95 \% \mathrm{CI},-0.15 \text { to }-0.13) \text {, } \\
\text { waist circumference by } 0.39 \mathrm{~cm}(95 \% \mathrm{CI} \text {, } \\
-0.64 \text { to }-0.14) \text {, } \\
\text { the sum of skin-fold thicknesses by } \\
0.63 \mathrm{~mm}(95 \% \mathrm{CI},-0.98 \text { to }-0.28) \text {. } \\
\text { lower offspring systolic }(-1.03 \mathrm{mmHg} \text {; } \\
95 \% \mathrm{CI},-1.65 \text { to }-0.42) \text { and diastolic } \\
\text { blood pressure }\end{array}$ \\
\hline $\begin{array}{l}\text { Fernandez-Barres } \\
\text { et al., 2016 [121] }\end{array}$ & Spain & $\begin{array}{l}\text { Population-based } \\
\text { 'Infancia y Medio } \\
\text { Ambiente' (INMA) birth } \\
\text { cohort study }\end{array}$ & 1827 mother-child pairs & $\begin{array}{l}\text { FFQ during 1st and 3rd } \\
\text { trimester }\end{array}$ & $\begin{array}{c}\text { Relative Mediterranean } \\
\text { diet score (rMED), final } \\
\text { potential score range was } \\
0-16\end{array}$ & $\begin{array}{c}\text { Anthropometry- } \\
\text { Overweight/obesity and } \\
\text { abdominal obesity based } \\
\text { on waist circumference at } 4 \\
\text { years }\end{array}$ & $\begin{array}{l}\text { Higher adherence to the MD in } \\
\text { pregnancy was not associated with } \\
\text { offspring overweight at age } 4 \text { years, but } \\
\text { there was some evidence of an inverse, } \\
\text { moderate association between maternal } \\
\text { rMED scores in pregnancy and offspring } \\
\text { waist circumference }\end{array}$ \\
\hline
\end{tabular}


Table 7. Cont

\begin{tabular}{|c|c|c|c|c|c|c|c|}
\hline First Author, Year & Country/Setting & Study Design & Population & $\begin{array}{l}\text { Maternal Dietary } \\
\text { Assessment Method }\end{array}$ & $\begin{array}{l}\text { Assessment of Adherence } \\
\text { to Diet/Dietary Score }\end{array}$ & $\begin{array}{c}\text { Long-term } \\
\text { Outcome/Median Child } \\
\text { Age }\end{array}$ & Key Findings \\
\hline $\begin{array}{c}\text { Okubo et al., } 2014 \\
\text { [122] }\end{array}$ & UK & $\begin{array}{l}\text { Prospective cohort - } \\
\text { Southampton Women's } \\
\text { Survey }\end{array}$ & 906 mother-child pairs & $\begin{array}{l}\text { FFQBetween 11-34-week } \\
\text { gestation }\end{array}$ & $\begin{array}{c}\text { GI and GL } \\
\text { GI values were obtained } \\
\text { from the GI database } \\
\text { published by the Medical } \\
\text { Research Council Human } \\
\text { Nutrition Research, UK } \\
\text { The GL of each food item } \\
\text { was determined by } \\
\text { multiplying the } \\
\text { carbohydrate content of } \\
\text { one serving by its GI value } \\
\text { (divided by 100) }\end{array}$ & $\begin{array}{l}\text { Body fat mass and lean } \\
\text { mass, } 4 \text { years and } 6 \text { years }\end{array}$ & $\begin{array}{l}\text { Maternal dietary GI in early (11 weeks) } \\
\text { pregnancy was positively associated } \\
\text { with fat mass at } 4 \text { and } 6 \text { years of age. } \\
\text { Maternal dietary GI in late ( } 34 \text { weeks) } \\
\text { pregnancy was also positively associated } \\
\text { with fat mass at } 4 \text { and } 6 \text { y of age, but } \\
\text { these associations were not robust to } \\
\text { adjustment for confounding factors }\end{array}$ \\
\hline
\end{tabular}




\subsection{DII}

Data regarding long-term associations of maternal dietary inflammation with offspring anthropometric outcomes are scarce. Sen et al. reported positive associations between maternal DII (measured during the first and second trimesters) and offspring anthropometric measures in mid-childhood (between ages 6 and 10), which included BMI z-score and waist circumference as well as more direct measures of adiposity such as fat mass index, fat-free mass index (FFMI), trunk fat mass index and fasting insulin [84]. The E-DII score was also recently analysed in the ALPHABET Consortium in 16,295 mother-child pairs from seven European birth cohorts. Higher early-pregnancy E-DII scores (indicating a more pro-inflammatory diet) tended to be associated with a higher odds of late-childhood [10.6 (1.2) years] overweight and obesity (OWOB) [OR $(95 \%$ CI) $1.09(1.00,1.19)$ per 1-SD E-DII score increase], whereas an inverse association was observed for late-pregnancy E-DII score and early-childhood [2.8 (0.3) years] OWOB [0.91 $(0.83,1.00)]$. In two cohorts with available data, a higher whole-pregnancy E-DII score was associated with a lower fat-free mass index in both mid-childhood and late-childhood [123]. In the Irish Lifeways cohort, there were no associations found between maternal dietary inflammation during pregnancy and childhood adiposity, whereas paternal line dietary inflammation appears to influence childhood obesity at both 5 and 9 years [24].

\subsection{Mediterranean Diet Score}

Chatzi et al. studied anthropometric outcomes in 997 mother-child pairs in the American Project Viva study in conjunction with 569 mother-child pairs from the Greek Rhea study. They found that maternal adherence to the MD during pregnancy was associated with lower child adiposity, leptin and blood pressure levels [120]. It is important to note that the Greek cohort is based on outcomes in early childhood at around 4 years compared to the American median age of 8 years. However, they report that these associations of MD scores in pregnancy with offspring adiposity were broadly similar in both cohorts when studied separately $[89,120]$.

The analysis of results from the Growing Up Today Study II across follow-up ages of 12-23 years indicate that greater maternal adherence to the Alternate Mediterranean Diet (aMED) score (adapted to the US population) showed similar findings with a lower risk of offspring overweight or obesity [116]. However, the results were not significant following adjustment for potential confounders including maternal pre-pregnancy BMI and lifestyle factors. It should be noted that childhood weight measures were self-reported in the study, which may lead to underreporting amongst adolescents with obesity [116]. In a Spanish study predicting long-term health outcome risks, the importance of tracking childhood adiposity rather than crude weight alone is underscored, because cardiometabolic risk factors are more prevalent in children and adolescents with abdominal obesity than those with general overweight/obesity $[121,124,125]$. The researchers reported that higher adherence to the relative Mediterranean diet score (rMED) in pregnancy was not associated with offspring overweight status at age 4 years. However, there was some evidence of an inverse, moderate association between the rMED in pregnancy and offspring waist circumference, a marker of abdominal obesity [121]. Furthermore, Donahue et al. have demonstrated a protective effect of prenatal omega-3 PUFAs (which is a key macronutrient in the Mediterranean diet) on adiposity in 3-year-olds [126].

\subsection{HEI and AHEI Scores}

Tahir et al. report that higher HEI-2015 scores during the third trimester of pregnancy were associated with lower infant body fat percentage at six months [119]. However, another study by Gonzalez-Nahm et al. in an American cohort found no association between AHEI-2010 scores in mid to late pregnancy and infant adiposity at birth, 6 or 12 months after adjustment for confounders such as maternal smoking, pre-pregnancy BMI, maternal ethnicity and maternal education [118]. Similarly, retrospective analysis by Strohmaier et al. found no associations between peripregnancy maternal adherence to the 
AHEI-2010 and offspring risk for obesity 12-23 years after adjustment for pre-pregnancy BMI and lifestyle factors [116]. Long-term studies using the modified AHEI-P are not yet available.

\subsection{DASH Score}

Despite its importance in controlling blood pressure and placental vascular flow, research regarding maternal DASH score associations with offspring adiposity and childhood obesity are scarce. Strohmaier et al. report an inverse association between peripregnancy DASH scores and offspring overweight risk at 12-23 years; however, this association was no longer observed after adjusting for maternal BMI and lifestyle factors before pregnancy [116]. Recent results from the ALPHABET Consortium in 16,295 mother-child pairs from seven European birth cohorts showed that higher maternal DASH score during pregnancy was associated with a lower odds of late-childhood OWOB (age-and-sex-specific BMI $z$-score $>85$ th percentile) as well as a lower late-childhood fat mass index (FMI) [123]. Interestingly, no consistent associations were observed between maternal DASH scores with regards to early- and mid-childhood OWOB (mean age range 2.8-6.1 years) [123].

\subsection{GI/GL}

Results from the Southampton Women's Survey of 907 mother-child dyads identified associations between higher maternal GI and GL with greater offspring adiposity (body-fat mass) at 4 and 6 years [122]. These results were found with early, but not late pregnancy GI and GL, highlighting the importance of the timing of the dietary assessment during pregnancy in the programming of adult disease susceptibility. However, more recent observational research based on the Lifeways cohort of generally healthy pregnant women found no clear associations between maternal GI and GL with childhood BMI, waist circumference z-scores and general or central obesity at 5 years [38]. In the Danish National Birth Cohort, higher maternal GI and GL were associated with an increase in 7-year BMI $z$-score in the unadjusted analysis. However, this association was no longer present after adjusting for previously mentioned confounders, particularly maternal pre-pregnancy BMI [117]. Similarly, a secondary adjusted analysis of the Irish ROLO cohort found no evidence that a low-GI diet in pregnancy impacts offspring anthropometry and body composition outcomes after 5 years' post-intervention [115]. Limited and inconsistent literature exist regarding maternal dietary scores and long-term childhood outcomes related to weight status and adiposity.

\section{The Role of the Placenta during Pregnancy}

\subsection{Placental Development}

The placenta plays a fundamental role in the various maternal-foetal exchanges during pregnancy and has endocrine functions that are essential for the maintenance of the pregnancy as well as for the development of the foetus [16]. Together with the umbilical cord, it provides for the direct transfer of nutrients, hormones and wastes between the mother and offspring. Originally formed from trophoblast cells during the implantation phase, the growth rate of the placenta is most rapid in the first trimester of pregnancy, a time when placental tissues are most sensitive to environmental perturbation [127,128]. Inadequate maternal nutrition or weight status can have major effects on the balance between the nutritional needs of the foetus and the placental capacity to meet them $[41,129]$.

Different markers of altered placental function reflected by weight, morphology, vascular development and transport function have been described. Markers of modifications in placental transport capacity include alterations of exchange surface area, barrier thickness and cell components of the different gestational ages of the placenta. These histopathological changes predispose to reduced nutrient transfer to the foetus. Additionally, vasculogenesis and angiogenesis are both critical processes to the maternal-foetal exchange. Vasculogenesis is de novo formation of blood vessels in the developing embryo while angiogenesis corresponds to new vessels from pre-existing vessels [17]. The foetal (birth 
weight) to placenta weight ratio at different gestational ages of placental development also been used, but collecting these measurements is often difficult in human studies [17,130]. Therefore, placental weight has been described as the most practical, studied marker of the available surface area for maternal foetal nutrient exchange [130-132]. Despite not being the only marker available, investigating the effects of dietary quality on placental weight could provide important insights, which may inform dietary guidelines or interventions to help prevent abnormalities in placental and subsequent child development.

Alterations in maternal nutritional status, such as undernutrition, have been described as impairing placental development and function, including placental weight, its function in transporting various nutrients, as well as its vascular development (de novo vessel formation) and the process of angiogenesis [17]. The pathogenesis of blood flow dysfunction such as pre-eclampsia may be established in early pregnancy when an inadequate remodelling of the spiral arteries occurs and leads to decreased perfusion of the placenta and development of the maternal syndrome in later pregnancy [133]. Oxidative stress and inflammatory mediators are also involved in the abnormal implantation associated with pre-eclampsia and IUGR, thus highlighting the role of diet quality in optimal implantation and placentation during the preconceptional period $[41,133]$. Consequently, inadequate placental development could lead to inappropriate foetal development and risk of IUGR $[41,129,133]$. Assessing the underlying vascular and inflammatory mechanisms associated with placental perfusion and transport efficiency is difficult in humans and most research has been limited to experimental animal models, specifically rats, mice and sheep. Conversely, other studies showed that maternal nutritional conditions such as hyperglycaemia and hyperinsulinemia are also likely to contribute to alterations in placental growth and weight [134]. However, more research is needed in investigating how early nutritional and metabolic change during pregnancy may affect placental development and lead to excessive neonatal adiposity. It is also important to note sex-specific placental adaptations that may drive differences in offspring growth [135]. In females, increased foeto-placental adaptability and placental reserve capacity result in increased survival rates at the expense of a reduced growth trajectory, whereas the opposite is observed in males [135]. Recent studies highlighted that sexual dimorphism may play a role in the impact of the placenta on infant anthropometry at birth, with significant findings seen in males but not females [136].

\subsection{Maternal Diet and Placental Development: Evidence from Animal Studies}

Starting with animal studies, some researchers have looked at the associations between high-fat diet or micronutrient and placental development [137]. Feeding pregnant rats a 'junk' food diet, characterised by high fat, high sugar and high salt, has demonstrated increased risk of adiposity in adult offspring [138]. These energy-dense diets often lead to overnutrition that is thought to elicit metabolic disturbances in placental development as well as foetal hyperglycaemia and hyperinsulinemia [127,128]. Across periconceptional rodent studies, there were no differences in foetal and placental weights where high-fat diets were given to rats compared to the control $[139,140]$. However, altered placental gene expression, with pathways promoting inflammation and growth being over-represented among up-regulated genes and those affecting apoptosis among down-regulated genes, has been observed following maternal high-fat feeding in pregnant rats [139]. Thus, multiple rodent studies highlight the impact of a high-fat diet on placental metabolism and thus on foetal programming for long-term offspring adiposity [141,142].

Other studies also evaluated the effect of specific micronutrients on placental development and inflammation. Reduced placental weight has been reported in severe iron deficiency in rats [137]. This is of note as further rat studies show that anaemia induces oxidative stress and inflammation in rat placentas, with elevated circulating levels of pro-inflammatory IL- 6 and TNF- $\alpha$ as well as oxidative damage (lipid peroxidation) and reduced antioxidant status $[137,143]$. Folate is directly able to scavenge free radicals while $B$ vitamins $\left(B_{2}, B_{6}\right.$ and $\left.B_{12}\right)$ also have antioxidant activity, thus playing an important role in early stages of placental development, including trophoblast invasion and angiogene- 
sis $[47,133]$. Moreover, folate-deficient mice were found to have decreased foetal weight and foetal/placental weight ratio [144]. Folate in particular is thought to play a key role in placental angiogenesis (critical for development of a normal placental circulation) by increasing the bioavailability of nitric oxide [17,47]. This is an important endothelium vasodilator, and its decreased bioavailability is associated with the production of reactive oxygen species involved in poor placental development [133,145]. Furthermore, maternal vitamin $B_{12}$ deficiency in rats altered placental phospholipid ratios, underscoring the potential of micronutrients in influencing placental development and composition [137].

\subsection{Maternal Diet and Placental Development: Evidence from Human Studies}

Maternal nutritional status during pregnancy plays a major role in foetal development, and accumulating evidence suggests that maternal hyperglycaemia may have adverse effects on embryonic and placental development [35]. Observational studies in the UK and Ireland have found that high carbohydrate intake during pregnancy could impair maternal insulin sensitivity, making higher levels of free glucose available for placental circulation, subsequently activating foetal glycogenesis and contributing to excess neonatal adiposity $[21,67,146]$. Such maternal overnutrition and as well as diabetes can also cause transient physiologic proinflammatory oxidative stress in the trophoblast, leading to a reduction in trophoblast growth in the placenta $[128,134]$. The link between dietary fat composition (fatty acid quantity and quality) and chronic disease risk is well established [147,148]. Maternal dietary fat intake has been shown to affect the fatty acid composition of lipids in foetal and newborn blood and developing tissues. By affecting the fatty acid supply to the foetus, differentiation in organs including the placenta can occur, which may in turn influence placental development and foetal programming $[127,148]$.

Excessive omega- 6 fatty acid intake and insufficient omega-3 fatty acid intake are two key components that adversely affect foetal programming [148]. An Icelandic observational study reported an inverse association between the proportion of long-chain omega-3 PUFAs in red blood cells of women in the 11th to 15th week of pregnancy and placental weight [133]. A moderate maternal dietary protein intake (10-25\% of total energy) is optimal for foetal growth and survival, as both low but also high protein intakes have been associated with lower birth weights and IUGR [21,149]. Possible mechanisms include reduced placental angiogenesis and reduced supply of nutrients from mother to foetus for low protein intakes. High maternal concentrations of amino acids (AA) leads to competition for AA transporters, resulting in reduced placental transport and umbilical uptake of AAs [149].

Other studies have evaluated the effect of micronutrients on placental development. In a prospective study of 1650 pregnancies, low iron status in early pregnancy was inversely related to placental size [150]. The synergistic use of vitamin $E$ and vitamin $C$ as antioxidants are important to consider in placental development due to their effect of inhibiting free radical formation to prevent oxidative stress and inflammatory placental damage [21]. Studies have demonstrated reduced placental perfusion and risk of pre-eclampsia arising from the placenta's limited antioxidant enzyme capacity in the first trimester [133]. The micronutrient immunomodulatory effects of Vitamin A, Vitamin D, folate and $B_{12}$ in in vitro/in vivo models of deficiency have also all demonstrated pro-inflammatory effects in the placenta including upregulation of pro-inflammatory cytokines [137].

However, research on maternal dietary score associations with placental development is scarce. In the Generation R cohort, women with low adherence to a Mediterranean diet pattern during early pregnancy had smaller placentas and also tended towards higher uteroplacental vascular resistance compared to those with high adherence to the MD pattern. However, it is important to note that an established, validated MD score was not used in this study [88]. Recent observational analysis in the same Dutch cohort found that in mid- and late- pregnancy, a higher maternal DASH diet score based on Fung's scoring method tended to be associated with lower umbilical artery vascular resistance and that lower maternal DASH score quartiles were associated with a higher umbilical artery 
pulsatility index (UmPI) [151]. The UmPI reflects the development of the fetoplacental vascular tree. Studies using the DII are more limited but early research suggests that oxidative stress or inflammation caused by a pro-inflammatory diet results in higher resistance and lower flow placental circulation [15]. This resultant mechanism leading to adverse foetal growth is thought to be more pronounced in obese pregnant women, who experience higher baseline inflammation and oxidative stress [15]. Further research on all of these validated maternal dietary score associations with placental development and inflammation is warranted.

\section{Epigenetic Mechanisms}

In 1942, Conrad H Waddington defined epigenetics as "the branch of biology that studies the causal interactions between genes and their products which bring the phenotype into being" [152]. Epigenetics was subsequently defined as the study of the mechanisms that regulate gene expression without alteration in the DNA sequence [153]. Epigenetic processes are essential for many organisms functions, but can be associated with major adverse health effects if they occur inappropriately [154]. Three main mechanisms are described in the literature: DNA methylation, histone modifications and noncoding RNAs [155]. DNA methylation, which is currently the easiest marker to measure and therefore the most studied in epidemiological studies, is the focus of this review.

\subsection{DNA Methylation and Developmental Plasticity}

Epigenetic modifications have been proposed as mechanisms by which a suboptimal nutrition state could contribute to the "developmental plasticity of the individual". Earlylife exposures have been described to be recorded in the "cellular memory" and having the potential to influence cellular functions with long-term effects $[18,156]$. The periconceptional period is a particular sensitive period for environmental exposures, due to major epigenetic processes that take place at the beginning of pregnancy [18]. Upon fertilisation, a global demethylation is observed, followed by de novo genome-wide methylation after implantation [18]. Thereafter, new methylation patterns are established from pluripotent cells in a lineage-specific manner leading to organ and tissue differentiation $[18,157]$. However, other studies showed that epigenetic marks are dynamic and modifiable under environmental conditions throughout the pregnancy and development [158] Several discoveries have highlighted the importance of DNA methylation for embryonic development, cell differentiation during development and the maintenance of tissue-specific gene expression patterns $[18,159]$. An inadequate environment during the periconception period may have an impact on epigenetic mechanisms, foetal programming and future health. Thus, the in utero environment, in particular maternal nutrition, has been described as one of the important factors in the modulation of gene expression [157]. This chapter reviews the current state of knowledge of maternal nutrition in DNA methylation changes. This review includes studies related to over- or undernutrition, glycaemic markers, the one-carbon metabolism (OCM) nutrients and a focus specifically on dietary quality and inflammation.

\subsection{Maternal Nutritional Intake and DNA Methylation}

The first evidence is based on findings from animal studies. Murine models have provided evidence about how early nutritional exposure is involved in epigenetic mechanisms, programming of the individual and its phenotype [18]. A classic example is the agouti gene, which is involved in determining coat colour in mice. In genetically identical mice, some have a brown coat and others a yellow coat [18]. The agouti viable yellow mouse is characterised by a yellow coat colour and an increased risk of obesity and hyperinsulinaemia. This is caused by a dominant mutation of the agouti locus, caused by the insertion of a so-called IAP (intracisternal A particle) repeat element, which acts as an alternative promoter. Hypomethylation of the promoter led to overexpression of the gene involved in the regulation of yellow pigment and other effects including obesity [18]. Conversely, when the percentage of methylation increases, the synthesis of the yellow pigment is regulated 
downwards, resulting in a brown or "pseudoagouti" coat [18]. One study showed that methyl-donor supplementation (folic acid, vitamin $B_{12}$, choline and betaine) was associated with hypermethylation of the agouti gene [160].

Recent human data are becoming available regarding the associations between maternal diet and DNA methylation. It has been described that some micronutrients are implicated in the one-carbon metabolism pathway, which supports multiple physiological processes, essential for human development including DNA methylation [19,161]. The main studies have focused on the associations between individual micronutrients, methyldonors and DNA methylation and the role of maternal over- and undernutrition. However, there are a limited number of human studies that have evaluated the relationship between dietary quality or inflammation state and offspring epigenetics.

\subsubsection{One-Carbon Metabolism Nutrients}

The Pune Maternal Nutrition Study cohort in India have provided evidence of the importance of the one-carbon metabolism in foetal programming [53]. OCM nutrients are described as carriers or methyl-group donors (e.g., folates, choline, betaine, methionine), or cofactors of enzymes involved in the transfer reactions of the methyl-groups to DNA (vitamins $B_{2}, B_{6}$, and $B_{12}$ ) [19]. Some studies have shown the implication of these micronutrients in offspring DNA methylation. Maternal dietary and supplemental intake of methyl-groups donors (folate, folic acid, betaine) in the preconception period can influence an infant's buccal DNA methylation patterns at 6 months old. The identified genes were associated with development, metabolism and appetite control [162]. In Gambia, it has been found that significant seasonal variations in maternal methyl-donor nutrient intake around the time of conception may influence levels of DNA methylation at metastable epialleles in offspring $[163,164]$. Metastable epialleles are genomic regions whose expression is determined in the early embryo and independently of cell differentiation [165]. Modifications at metastable epialleles can lead to permanent phenotypic consequences $[163,165]$. Another study has investigated the relationship between serum levels of folate, vitamin $\mathrm{B}_{12}$ and methylation of the imprinted genes insulin-like growth factor 2 (IGF2) in maternal and cord blood. IGF2 is a key factor in human growth and development. The methylation patterns of IGF2 in promoter 3 of cord blood samples were negatively associated with serum levels of vitamin $B_{12}$ only in maternal blood [166]. Other results reported significant associations between maternal folic acid intake in early pregnancy and offspring DNA methylation in the control of imprinted genes (IGF2) and transposable elements such as long interspersed nuclear element 1 (LINE-1) [18,167]. One RCT has confirmed these results by showing that folic acid supplementation during pregnancy compared with placebo results in significant changes in cord blood DNA methylation in genes involved in growth and brain development [168]. However, most of the previous studies are observational and, thus, by design cannot provide direct causal link between micronutrient intake and epigenetic effects in offspring. Moreover, further research is needed investigating the combined intake of OCM nutrients, the interactions among nutrients and those that may indirectly affect the DNA methylation process [19].

\subsubsection{Interventional Studies on Glycaemic Index}

In recent years, some interventional studies have focused on the impact of GI dietary intervention in mothers during pregnancy and evaluated their relation to DNA methylation in the progeny. Exposure to adverse conditions during pregnancy like GDM is increasing and has been largely shown to affect foetal development [169]. New evidence also supports the epigenetic role in metabolic development of newborns exposed to maternal hyperglycaemia during pregnancy [169]. The ROLO study, an RCT, investigated the impact of a low GI dietary intervention during pregnancy on DNA methylation in cord blood at birth by using a genome-wide approach [170]. No individual probes remained significantly differentially methylated between the intervention and control groups after adjusting for multiple tests. Nevertheless, hierarchical clustering of the top 1000 unadjusted differ- 
entially methylated probes revealed two methylation clusters in the intervention study and maternal BMI difference between the two groups (intervention/control) [170]. In the same cohort, they also recently evaluated the epigenetic patterns on saliva samples of 63 infants at 5 years old, following the intervention during pregnancy. Gene pathway analysis identified three functional clusters involved in insulin secretion and resistance for which there were differences between the intervention and control groups [171]. One small clinical trial of 24 women has provided evidence suggesting that maternal dietary GI modifications during pregnancy may affect placental DNA methylation of insulin regulation genes [172]. The UK Pregnancies Better Eating and Activity Trial (UPBEAT) RCT has evaluated the effect of lifestyle intervention (low GI diet plus physical activity) v standard care in 557 pregnant women with obesity. They showed that the methylation changes observed with maternal GDM exposure appeared to be reduced by the pregnancy lifestyle intervention [173]. However, interventional studies on maternal diet during pregnancy as assessed by candidate gene approach remain scarce.

\subsubsection{Maternal Under- and Over-Nutrition}

Several animal studies have reported that maternal overnutrition or dietary restriction were associated with direct consequences on foetal development. Some investigations conducted in murine models reported that maternal overnutrition programs long-term epigenetic modifications [174-176]. A study on maternal high-fat (HF) diet during 4 weeks before and during gestation caused hyperglycaemia and insulinemic resistance in male offspring as well as modification in gene methylation in the offspring liver [174]. In another study, female rats were fed low-fat or HF diet for 6- weeks before pregnancy and during pregnancy. Maternal overnutrition was associated with long-term epigenetic alterations in the offspring's hypothalamic Proopiomelanocortin (POMC) promoter. The POMC gene is described as a key factor in the control of energy balance [175]. Other results indicate that modest dietary protein restriction during pregnancy may alter the phenotype through epigenetic changes in specific genes [177].

Epidemiological studies conducted in humans have also linked the impact of maternal under- and over-nutrition during critical periods of development with the child development [178]. One of the most significant studies was conducted in children from mothers exposed to the Dutch famine during the periconceptional period and reported a reduced level of methylation of the imprinted gene IGF2 in the adulthood [179]. These results reinforce the periconception period as a crucial period for maintaining epigenetic marks. Recently, in the context of increasing prevalence of childhood obesity, several studies have evaluated the impact of maternal obesity or excessive gestational weight gain on many adverse child outcomes through epigenetic mechanisms. In the Newborn Epigenetics study (NEST) cohort, maternal pre-pregnancy BMI was associated with CpG variations measured in cord blood leukocytes [180]. It has been shown that the methylation differences at $\mathrm{CpG}$ sites located in the TAP Binding Protein (TAPBP) gene were associated with BMI z-score and systolic blood pressure (BP) percentile in female and systolic and diastolic BP percentile in male offspring at 5 years [180]. Recent observations from the Avon Longitudinal Study of Parents and Children (ALSPAC) cohort identified several CpG sites that are differentially methylated in the cord blood of offspring of obese mothers compared with offspring of normal weight mothers [181]. However, no association between gestational weight gain and DNA methylation has been found [181]. A meta-analysis of 19 cohorts found associations between maternal adiposity and variations in newborn blood DNA methylation [182].

\subsubsection{Dietary Quality and Inflammation}

While more research concerning maternal obesity and individual micronutrient intake and offspring epigenetics has been conducted, far fewer studies have examined dietary patterns or specific types of maternal diets, which yet reflects dietary quality and food interactions. 
The MD pattern has also been associated with higher intake of specific nutrients such as folates that have been shown to influence DNA methylation [183]. However, few studies have evaluated the associations between the MD and epigenetic outcomes. The effects of the MD were assessed in 390 mother-child pairs from the NEST cohort, in nine regions of imprinted genes selected for their involvement in embryonic growth regulation and brain development [183]. They observed a decreased level of methylation at the MEG3-IG DMR in cord blood leukocyte among girls, in response to lower maternal adherence to a MD pattern in early pregnancy [183]. One other publication from the NEST cohort has shown perinatal MD score associations with sex-dependent methylation differences for imprinted control regions of MEG3, IGF2, PLAGL1 and SGCE/PEG10 in cord blood samples [184]. Genomic imprinting is an epigenetic mechanism that leads to the monoallelic expression of genes in a parent-of-origin-dependent manner [185]. Imprinted gene DNA methylation is largely established in the developing gametes and maintained in somatic cells, making it as an important indicator of early exposures [183]. There are few published studies on the relations between the MD and epigenetic outcomes; however. the MD has been largely recommended for its ability to reduce inflammation and improve long-term outcomes in adults [183]. Further research is needed to understand the potential mechanisms.

Inflammation has recently been proposed as another pathway by which maternal diet could affect the epigenome [14]. The hormonal and immunological changes that occur during pregnancy are necessary to support a healthy pregnancy and induce an anti-inflammatory state [186]. Chronic inflammation state during pregnancy, observed in obese women, has been associated with many adverse pregnancy outcomes such as prematurity and LBW [14,87]. Emerging evidence showed the role of chronic inflammation during pregnancy on foetal programming, but the underlying mechanisms are still poorly understood [85]. One study tested the association between the E-DII during pregnancy and both offspring methylation of differentially methylated regions of imprinted gene $(n=338)$ and circulating cytokines $(n=105)$ [14]. Although no associations were observed between E-DII and cytokines levels or offspring methylation in infant cord blood, they found that inflammatory cytokine concentrations were associated with lower methylation at the MEG3 imprinted gene [14]. Despite their null findings between maternal E-DII score and DNA methylation, positive associations were reported with birth outcomes suggesting a potential role of inflammatory diet in child development, irrespective of the underlying mechanism. While limited, there is accumulating evidence of an association between maternal inflammatory conditions and offspring methylation.

In summary, it has been largely shown that specific micronutrients are involved in the DNA methylation process; however, further investigations regarding the potential role of maternal dietary quality or inflammation are necessary.

\section{Conclusions and Future Directions \\ 8.1. Summary and Discussion of Results}

In this review, we examined and summarised findings from a growing body of research investigating associations between maternal dietary inflammatory potential and dietary quality, determined by various scores and foetal development, childhood adiposity, placental measures and epigenetics. The main results suggest that diets of the highest quality, as assessed by the HEI, AHEI, MD, DASH and GI/GL scores, during pregnancy are beneficial for a wide range of maternal and offspring outcomes. However, findings in human studies remain inconsistent.

The evidence regarding DII and E-DII scores highlight the importance of having a less pro-inflammatory diet in pregnant women for improving birth outcomes and reducing the risk of prematurity. The findings in relation to dietary quality associations with long-term child development and placenta development are either conflicting or limited. Finally, few studies investigating relationships between dietary scores and DNA methylation exist. Thus, future research investigating the potential influence of dietary inflammatory status and dietary quality on these outcomes is warranted. 
The observed heterogeneity of study populations, ethnicity, differences in dietary assessment methods, timing of dietary assessment and outcome measures may contribute to the observed inconsistent results. Most studies are observational in nature, thus causality cannot be established. However, it has been shown that low-GI dietary intervention may lead to decreased risk of adverse neonatal outcomes [36]. These observations encourage future investigation including RCTs. Finally, another limitation related to nutritional epidemiology is the lack of precision in measuring diet in all its complexity. Although some recent scores like the DII were designed to be comparable across populations [30], information on food consumption was self-reported by women in several studies, which might be subject to recall bias and measurement errors.

\subsection{Future Perspectives}

Most of the research to date regarding early life nutritional programming has focused on the mother but emerging evidence suggests that paternal nutritional status may also have an effect on child development, independently of maternal diet [24,104]. In a study conducted in Ireland, higher paternal E-DII scores, indicating a more pro-inflammatory diet, were associated with increased risk of childhood OWOB at 5 years [24], whereas higher paternal HEI scores, indicating higher dietary quality, were associated with reduced risk of childhood obesity [104]. Other studies reported that higher paternal BMI at conception was associated with increased offspring BMI [187]. In an American cohort study including 429 father-child pairs, paternal BMI, independently of maternal BMI, was associated with offspring epigenetic modifications at birth and at ages 3 years and 7 years [188]. Moreover, fathers have been described as important contributors of family food practices [189]. Interventions during the pre-conception period should include both parents and consider other family-based health behaviours such as physical activity and sedentary behaviour, which play an important role. Moreover, recent studies showed sex-specific foetal growth patterns associated with maternal healthy lifestyle [100]. This sexual dimorphism might arise from differences in foetal programming and responses to adverse intrauterine exposure. Further research is needed to understand if these may have different implications on long-term health among males and females [190]. Further research to ascertain mechanisms linking maternal diet with health outcomes in offspring is needed. Epigenetic ageing may be a mechanistic link between early-life exposures and risk of adult disease [191]. A recent study reported that a pro-inflammatory, immunological state during pregnancy was associated with shorter offspring telomere length [192]. Telomere biology plays a fundamental role in maintaining genome and cell integrity, and shortened telomere is a well-established indicator of the ageing processes [193]. Further research elucidating such mechanisms is required.

In conclusion, improving our understanding of parental nutritional programming may help inform the development of more effective public health messages, diet and lifestyle interventions and pregnancy guidelines to promote intergenerational health and longevity. Several studies have shown that dietary quality and dietary inflammation state during pregnancy play a role in child development, even if results from some studies remain inconsistent or limited. Strategies aiming to promote adherence to a less proinflammatory and better-quality diet across all stages of maternal and childhood life may be of considerable importance to public health.

Author Contributions: All authors contributed to this review: Conceptualization: C.M.P. and M.L.; writing original draft preparation: M.L., S.T. and C.M.P.; manuscript review and editing of final draft: M.L., S.T. and C.M.P. All authors have read and agreed to the published version of the manuscript.

Funding: This work was supported by an award from the European Union's Horizon 2020 research and innovation programme under the ERA-Net Cofund of the Joint Programming Initiative Healthy Diet for Healthy Life (JPI-HDHL) (http: / / www.healthydietforhealthylife.eu accessed on 10 March 2021) action number 696295 (Biomarkers for Nutrition and Health). Co-funding was provided by Science Foundation Ireland, Ireland (Grant Number SFI/16/ERA-HDHL/3360). This work was also supported by an Ad Astra Fellowship and Studentship from University College Dublin, Ireland. The 
funders had no role in the design of the study; in the collection, analyses, or interpretation of data; in the writing of the manuscript, or in the decision to publish the results.

Institutional Review Board Statement: Not applicable.

Informed Consent Statement: Not applicable.

Data Availability Statement: Not applicable.

Conflicts of Interest: The authors declare no conflict of interest.

\section{Abbreviations}

$\begin{array}{ll}\text { AA } & \text { Amino acids } \\ \text { AGA } & \text { Appropriate for gestational age } \\ \text { AHEI } & \text { Alternative Healthy Eating Index } \\ \text { AHEI-P } & \text { Alternate Healthy Eating Index for Pregnancy } \\ \text { ALSPAC } & \text { Avon Longitudinal Study of Parents and Children } \\ \text { aMED } & \text { Alternate Mediterranean Diet } \\ \text { BMI } & \text { Body mass index } \\ \text { BP } & \text { Blood pressure } \\ \text { CHO } & \text { Carbohydrate } \\ \text { CVD } & \text { Cardiovascular disease } \\ \text { DASH } & \text { Dietary Approaches to Stop Hypertension } \\ \text { DHA } & \text { Docosahexaenoic acid } \\ \text { DII } & \text { Dietary inflammatory index } \\ \text { DNBC } & \text { Danish National Birth Cohort } \\ \text { E-DII } & \text { Energy-adjusted DII } \\ \text { EPA } & \text { Eicosapentaenoic acid } \\ \text { FA } & \text { Fatty acids } \\ \text { FMI } & \text { Fat mass index } \\ \text { FFMI } & \text { Fat-free mass index } \\ \text { FFQs } & \text { Food frequency questionnaires } \\ \text { FGR } & \text { Foetal growth restriction } \\ \text { GDM } & \text { Gestational diabetes mellitus } \\ \text { GI } & \text { Glycaemic Index } \\ \text { GL } & \text { Glycaemic Load } \\ \text { HEI } & \text { Healthy Eating Index } \\ \text { HF } & \text { High-fat } \\ \text { IGF2 } & \text { Insulin-like growth factor 2 } \\ \text { II } & \text { Insulinemic index } \\ \text { IL } & \text { Insulinemic load } \\ \text { INMA } & \text { Infancia y Medio Ambiente birth cohort study } \\ \text { IUGR } & \text { Intrauterine growth retardation } \\ \text { LBW } & \text { Low birth weight } \\ \text { LGA } & \text { Large for gestational age } \\ \text { LINE-1 } & \text { Interspersed nuclear element 1 } \\ \text { MD } & \text { Mediterranean diet } \\ \text { MDS } & \text { MD Score } \\ \text { MDScale } & \text { Mediterranean Diet Scale } \\ \text { MEDLIFE } & \text { Mediterranean Lifestyle } \\ \text { MetS } & \text { Metabolic syndrome } \\ \text { MFP } & \text { Mediterranean Food Pattern index } \\ \text { NEST } & \text { Newborn Epigenetics study } \\ \text { NTD } & \text { Neural tube defects } \\ \text { OCM } & \text { One-carbon metabolism } \\ & \end{array}$




$\begin{array}{ll}\text { OWOB } & \text { Overweight and obesity } \\ \text { POMC } & \text { Proopiomelanocortin } \\ \text { PUFA } & \text { Polyunsaturated fatty acids } \\ \text { RCTs } & \text { Randomised controlled trials } \\ \text { rMED } & \text { Relative Mediterranean diet score } \\ \text { SGA } & \text { Small for gestational age } \\ \text { TAPBP } & \text { TAP Binding Protein gene } \\ \text { T2DM } & \text { Type 2 diabetes mellitus } \\ \text { UmPI } & \text { Umbilical artery pulsatility index } \\ \text { UPBEAT } & \text { UK Pregnancies Better Eating and Activity Trial } \\ \text { USDA } & \text { United States Department of Agriculture. }\end{array}$

\section{References}

1. $\quad$ Barker, D.J.P. Mothers, Babies and Health in Later Life; Churchill Livingstone: Edinburgh, UK, 1998.

2. Painter, R.C.; Roseboom, T.J.; Bleker, O.P. Prenatal exposure to the Dutch famine and disease in later life: An overview. Reprod. Toxicol. 2005, 20, 345-352. [CrossRef]

3. $\quad$ Fleming, T.P.; Watkins, A.J.; Velazquez, M.A.; Mathers, J.C.; Prentice, A.M.; Stephenson, J.; Barker, M.; Saffery, R.; Yajnik, C.S.; Eckert, J.J.; et al. Origins of lifetime health around the time of conception: Causes and consequences. Lancet 2018, 391, 1842-1852. [CrossRef]

4. $\quad$ Barker, D.J.; Gluckman, P.D.; Godfrey, K.M.; Harding, J.E.; Owens, J.A.; Robinson, J.S. Fetal nutrition and cardiovascular disease in adult life. Lancet 1993, 341, 938-941. [CrossRef]

5. Gluckman, P.D.; Hanson, M.A.; Cooper, C.; Thornburg, K.L. Effect of In Utero and Early-Life Conditions on Adult Health and Disease. N. Engl. J. Med. 2008, 359, 61-73. [CrossRef]

6. Barker, D.J.; Osmond, C. Infant mortality, childhood nutrition, and ischaemic heart disease in England and Wales. Lancet 1986, 1, 1077-1081. [CrossRef]

7. Hales, C.N.; Barker, D.J. Type 2 (non-insulin-dependent) diabetes mellitus: The thrifty phenotype hypothesis. Diabetologia 1992, 35, 595-601. [CrossRef]

8. Osmond, C.; Barker, D.J.; Winter, P.D.; Fall, C.H.; Simmonds, S.J. Early growth and death from cardiovascular disease in women. BMJ 1993, 307, 1519-1524. [CrossRef] [PubMed]

9. Dabelea, D.; Mayer-Davis, E.J.; Lamichhane, A.P.; D’Agostino, R.B.; Liese, A.D.; Vehik, K.S.; Narayan, K.M.V.; Zeitler, P.; Hamman, R.F. Association of intrauterine exposure to maternal diabetes and obesity with type 2 diabetes in youth: The SEARCH Case-Control Study. Diabetes Care 2008, 31, 1422-1426. [CrossRef] [PubMed]

10. McMillen, I.C.; MacLaughlin, S.M.; Muhlhausler, B.S.; Gentili, S.; Duffield, J.L.; Morrison, J.L. Developmental origins of adult health and disease: The role of periconceptional and foetal nutrition. Basic Clin. Pharmacol. Toxicol. 2008, 102, 82-89. [CrossRef]

11. Michels, K.B.; Schulze, M.B. Can dietary patterns help us detect diet-disease associations? Nutr. Res. Rev. 2005, 18, 241-248. [CrossRef]

12. Wirt, A.; Collins, C.E. Diet quality-what is it and does it matter? Public Health Nutr. 2009, 12, 2473-2492. [CrossRef]

13. Doyle, I.M.; Borrmann, B.; Grosser, A.; Razum, O.; Spallek, J. Determinants of dietary patterns and diet quality during pregnancy: A systematic review with narrative synthesis. Public Health Nutr. 2017, 20, 1009-1028. [CrossRef] [PubMed]

14. McCullough, L.E.; Miller, E.E.; Calderwood, L.E.; Shivappa, N.; Steck, S.E.; Forman, M.R.; Mendez, M.A.; Maguire, R.; Fuemmeler, B.F.; Kollins, S.H.; et al. Maternal inflammatory diet and adverse pregnancy outcomes: Circulating cytokines and genomic imprinting as potential regulators? Epigenetics 2017, 12, 688-697. [CrossRef] [PubMed]

15. Sen, S.; Rifas-Shiman, S.L.; Shivappa, N.; Wirth, M.D.; Hébert, J.R.; Gold, D.R.; Gillman, M.W.; Oken, E. Dietary Inflammatory Potential during Pregnancy Is Associated with Lower Fetal Growth and Breastfeeding Failure: Results from Project Viva. J. Nutr. 2016, 146, 728-736. [CrossRef]

16. Jansson, T.; Powell, T.L. Role of the placenta in fetal programming: Underlying mechanisms and potential interventional approaches. Clin. Sci. 2007, 113, 1-13. [CrossRef] [PubMed]

17. Belkacemi, L.; Nelson, D.M.; Desai, M.; Ross, M.G. Maternal Undernutrition Influences Placental-Fetal Development. Biol. Reprod. 2010, 83, 325-331. [CrossRef]

18. Dominguez-Salas, P.; Cox, S.E.; Prentice, A.M.; Hennig, B.J.; Moore, S.E. Maternal nutritional status, C(1) metabolism and offspring DNA methylation: A review of current evidence in human subjects. Proc. Nutr. Soc. 2012, 71, 154-165. [CrossRef] [PubMed]

19. Anderson, O.S.; Sant, K.E.; Dolinoy, D.C. Nutrition and epigenetics: An interplay of dietary methyl donors, one-carbon metabolism, and DNA methylation. J. Nutr. Biochem. 2012, 23, 853-859. [CrossRef]

20. Monthé-Drèze, C.; Rifas-Shiman, S.L.; Aris, I.M.; Shivappa, N.; Hebert, J.R.; Sen, S.; Oken, E. Maternal diet in pregnancy is associated with differences in child body mass index trajectories from birth to adolescence. Am. J. Clin. Nutr. 2021. [CrossRef]

21. Mousa, A.; Naqash, A.; Lim, S. Macronutrient and Micronutrient Intake during Pregnancy: An Overview of Recent Evidence. Nutrients 2019, 11, 443. [CrossRef] 
22. Oh, C.; Keats, E.C.; Bhutta, Z.A. Vitamin and Mineral Supplementation During Pregnancy on Maternal, Birth, Child Health and Development Outcomes in Low- and Middle-Income Countries: A Systematic Review and Meta-Analysis. Nutrients 2020, $12,491$. [CrossRef]

23. Gleason, P.M.; Boushey, C.J.; Harris, J.E.; Zoellner, J. Publishing nutrition research: A review of multivariate techniques-part 3: Data reduction methods. J. Acad. Nutr. Diet. 2015, 115, 1072-1082. [CrossRef]

24. Navarro, P.; Shivappa, N.; Hébert, J.R.; Mehegan, J.; Murrin, C.M.; Kelleher, C.C.; Phillips, C.M. Intergenerational associations of dietary inflammatory index with birth outcomes and weight status at age 5 and 9: Results from the Lifeways cross-generation cohort study. Pediatr. Obes. 2020, 15, e12588. [CrossRef] [PubMed]

25. Phillips, C.M.; Chen, L.W.; Heude, B.; Bernard, J.Y.; Harvey, N.C.; Duijts, L.; Mensink-Bout, S.M.; Polanska, K.; Mancano, G.; Suderman, M.; et al. Dietary Inflammatory Index and Non-Communicable Disease Risk: A Narrative Review. Nutrients 2019, 11, 1873. [CrossRef]

26. Soltani, S.; Arablou, T.; Jayedi, A.; Salehi-Abargouei, A. Adherence to the dietary approaches to stop hypertension (DASH) diet in relation to all-cause and cause-specific mortality: A systematic review and dose-response meta-analysis of prospective cohort studies. Nutr. J. 2020, 19, 37. [CrossRef] [PubMed]

27. Morze, J.; Danielewicz, A.; Hoffmann, G.; Schwingshackl, L. Diet Quality as Assessed by the Healthy Eating Index, Alternate Healthy Eating Index, Dietary Approaches to Stop Hypertension Score, and Health Outcomes: A Second Update of a Systematic Review and Meta-Analysis of Cohort Studies. J. Acad. Nutr. Diet. 2020, 120, 1998-2031.e1915. [CrossRef] [PubMed]

28. Aljuraiban, G.S.; Gibson, R.; Oude Griep, L.M.; Okuda, N.; Steffen, L.M.; Van Horn, L.; Chan, Q. Perspective: The Application of A Priori Diet Quality ScoRes. to Cardiovascular Disease Risk-A Critical Evaluation of Current Scoring Systems. Adv. Nutr. 2020, 11, 10-24. [CrossRef] [PubMed]

29. Shivappa, N.; Steck, S.E.; Hurley, T.G.; Hussey, J.R.; Hébert, J.R. Designing and developing a literature-derived, population-based dietary inflammatory index. Public Health Nutr. 2014, 17, 1689-1696. [CrossRef]

30. Hébert, J.R.; Shivappa, N.; Wirth, M.D.; Hussey, J.R.; Hurley, T.G. Perspective: The Dietary Inflammatory Index (DII)-Lessons Learned, Improvements Made, and Future Directions. Adv. Nutr. 2019, 10, 185-195. [CrossRef] [PubMed]

31. Cavicchia, P.P.; Steck, S.E.; Hurley, T.G.; Hussey, J.R.; Ma, Y.; Ockene, I.S.; Hébert, J.R. A New Dietary Inflammatory Index Predicts Interval Changes in Serum High-Sensitivity C-Reactive Protein. J. Nutr. 2009, 139, 2365-2372. [CrossRef]

32. World Health Organisation. Macronutrients. Available online: http://www.emro.who.int/health-topics/macronutrients/index. html (accessed on 2 June 2021).

33. Fogelholm, M.; Anderssen, S.; Gunnarsdottir, I.; Lahti-Koski, M. Dietary macronutrients and food consumption as determinants of long-term weight change in adult populations: A systematic literature review. Food Nutr. Res. 2012, 56, 19103. [CrossRef] [PubMed]

34. Brion, M.-J.A.; Ness, A.R.; Rogers, I.; Emmett, P.; Cribb, V.; Davey Smith, G.; Lawlor, D.A. Maternal macronutrient and energy intakes in pregnancy and offspring intake at $10 \mathrm{y}$ : Exploring parental comparisons and prenatal effects. Am. J. Clin. Nutr. 2010, 91, 748-756. [CrossRef]

35. Wahab, R.J.; Scholing, J.M.; Gaillard, R. Maternal early pregnancy dietary glycemic index and load, fetal growth, and the risk of adverse birth outcomes. Eur. J. Nutr. 2020. [CrossRef] [PubMed]

36. Zhang, R.; Han, S.; Chen, G.C.; Li, Z.N.; Silva-Zolezzi, I.; Parés, G.V.; Wang, Y.; Qin, L.Q. Effects of low-glycemic-index diets in pregnancy on maternal and newborn outcomes in pregnant women: A meta-analysis of randomized controlled trials. Eur. J. Nutr. 2018, 57, 167-177. [CrossRef] [PubMed]

37. Jenkins, D.J.; Wolever, T.M.; Taylor, R.H.; Barker, H.; Fielden, H.; Baldwin, J.M.; Bowling, A.C.; Newman, H.C.; Jenkins, A.L.; Goff, D.V. Glycemic index of foods: A physiological basis for carbohydrate exchange. Am. J. Clin. Nutr. 1981, 34, 362-366. [CrossRef]

38. Chen, L.W.; Navarro, P.; Murrin, C.M.; Mehegan, J.; Kelleher, C.C.; Phillips, C.M. Maternal Dietary Glycemic and Insulinemic Indexes Are Not Associated with Birth Outcomes or Childhood Adiposity at 5 Years of Age in an Irish Cohort Study. J. Nutr. 2019, 149, 1037-1046. [CrossRef]

39. Jayedi, A.; Soltani, S.; Jenkins, D.; Sievenpiper, J.; Shab-Bidar, S. Dietary glycemic index, glycemic load, and chronic disease: An umbrella review of meta-analyses of prospective cohort studies. Crit. Rev. Food Sci. Nutr. 2020, 60. [CrossRef]

40. Gomes, C.B.; Malta, M.B.; Antunes, J.L.F.; Gallo, C.O.; Benício, M.H.D.; Carvalhaes, M. The association of dietary glycaemic index and glycaemic load with gestational weight gain and newborn birth weight. Br. J. Nutr. 2020, 123, 818-825. [CrossRef]

41. Cetin, I.; Bühling, K.; Demir, C.; Kortam, A.; Prescott, S.L.; Yamashiro, Y.; Yarmolinskaya, M.; Koletzko, B. Impact of Micronutrient Status during Pregnancy on Early Nutrition Programming. Ann. Nutr. Metab. 2019, 74, 269-278. [CrossRef] [PubMed]

42. World Health Organisation. Micronutrients. Available online: https://www.who.int/health-topics/micronutrients\#tab=tab_1 (accessed on 2 June 2021).

43. Miller, V.; Webb, P.; Micha, R.; Mozaffarian, D. Defining diet quality: A synthesis of dietary quality metrics and their validity for the double burden of malnutrition. Lancet Planet. Health 2020, 4, e352-e370. [CrossRef]

44. Diemert, A.; Lezius, S.; Pagenkemper, M.; Hansen, G.; Drozdowska, A.; Hecher, K.; Arck, P.; Zyriax, B.C. Maternal nutrition, inadequate gestational weight gain and birth weight: Results from a prospective birth cohort. BMC Pregnancy Childbirth 2016, 16, 224. [CrossRef] [PubMed] 
45. Horan, M.K.; McGowan, C.A.; Gibney, E.R.; Donnelly, J.M.; McAuliffe, F.M. The association between maternal dietary micronutrient intake and neonatal anthropometry-secondary analysis from the ROLO study. Nutr. J. 2015, 14, 105. [CrossRef] [PubMed]

46. Lazarus, J.H. Iodine status in europe in 2014. Eur. Thyroid J. 2014, 3, 3-6. [CrossRef]

47. Williams, P.J.; Bulmer, J.N.; Innes, B.A.; Broughton Pipkin, F. Possible Roles for Folic Acid in the Regulation of Trophoblast Invasion and Placental Development in Normal Early Human Pregnancy. Biol. Reprod. 2011, 84, 1148-1153. [CrossRef]

48. McGee, M.; Bainbridge, S.; Fontaine-Bisson, B. A crucial role for maternal dietary methyl donor intake in epigenetic programming and fetal growth outcomes. Nutr. Rev. 2018, 76, 469-478. [CrossRef]

49. Caffrey, A.; McNulty, H.; Irwin, R.E.; Walsh, C.P.; Pentieva, K. Maternal folate nutrition and offspring health: Evidence and current controversies. Proc. Nutr. Soc. 2019, 78, 208-220. [CrossRef]

50. Morse, N.L. Benefits of docosahexaenoic acid, folic acid, vitamin D and iodine on foetal and infant brain development and function following maternal supplementation during pregnancy and lactation. Nutrients 2012, 4, 799-840. [CrossRef]

51. De-Regil, L.M.; Peña-Rosas, J.P.; Fernández-Gaxiola, A.C.; Rayco-Solon, P. Effects and safety of periconceptional oral folate supplementation for preventing birth defects. Cochrane Database Syst. Rev. 2015, Cd007950. [CrossRef] [PubMed]

52. Yajnik, C.S.; Deshmukh, U.S. Fetal programming: Maternal nutrition and role of one-carbon metabolism. Rev. Endocr. Metab. Disord. 2012, 13, 121-127. [CrossRef] [PubMed]

53. Yajnik, C.S.; Deshpande, S.S.; Jackson, A.A.; Refsum, H.; Rao, S.; Fisher, D.J.; Bhat, D.S.; Naik, S.S.; Coyaji, K.J.; Joglekar, C.V.; et al. Vitamin B12 and folate concentrations during pregnancy and insulin resistance in the offspring: The Pune Maternal Nutrition Study. Diabetologia 2008, 51, 29-38. [CrossRef]

54. Aoun, C.; Papazian, T.; Helou, K.; El Osta, N.; Khabbaz, L.R. Comparison of five international indices of adherence to the Mediterranean diet among healthy adults: Similarities and differences. Nutr. Res. Pract. 2019, 13, 333-343. [CrossRef]

55. Zaragoza-Martí, A.; Cabañero-Martínez, M.J.; Hurtado-Sánchez, J.A.; Laguna-Pérez, A.; Ferrer-Cascales, R. Evaluation of Mediterranean diet adherence scores: A systematic review. BMJ. Open 2018, 8, e019033. [CrossRef]

56. Guenther, P.M.; Casavale, K.O.; Reedy, J.; Kirkpatrick, S.I.; Hiza, H.A.; Kuczynski, K.J.; Kahle, L.L.; Krebs-Smith, S.M. Update of the Healthy Eating Index: HEI-2010. J. Acad. Nutr. Diet. 2013, 113, 569-580. [CrossRef] [PubMed]

57. Krebs-Smith, S.M.; Pannucci, T.E.; Subar, A.F.; Kirkpatrick, S.I.; Lerman, J.L.; Tooze, J.A.; Wilson, M.M.; Reedy, J. Update of the Healthy Eating Index: HEI-2015. J. Acad Nutr. Diet 2018, 118, 1591-1602. [CrossRef] [PubMed]

58. Al-Ibrahim, A.A.; Jackson, R.T. Healthy eating index versus alternate healthy index in relation to diabetes status and health markers in U.S. adults: NHANES 2007-2010. Nutr. J. 2019, 18, 26. [CrossRef] [PubMed]

59. Schwingshackl, L.; Bogensberger, B.; Hoffmann, G. Diet Quality as Assessed by the Healthy Eating Index, Alternate Healthy Eating Index, Dietary Approaches to Stop Hypertension Score, and Health Outcomes: An Updated Systematic Review and Meta-Analysis of Cohort Studies. J. Acad. Nutr. Diet. 2018, 118, 74-100.e111. [CrossRef] [PubMed]

60. Fung, T.T.; Chiuve, S.E.; McCullough, M.L.; Rexrode, K.M.; Logroscino, G.; Hu, F.B. Adherence to a DASH-style diet and risk of coronary heart disease and stroke in women. Arch. Intern. Med. 2008, 168, 713-720. [CrossRef] [PubMed]

61. Sacks, F.M.; Obarzanek, E.; Windhauser, M.M.; Svetkey, L.P.; Vollmer, W.M.; McCullough, M.; Karanja, N.; Lin, P.H.; Steele, P.; Proschan, M.A.; et al. Rationale and design of the Dietary Approaches to Stop Hypertension trial (DASH). A multicenter controlled-feeding study of dietary patterns to lower blood pressure. Ann. Epidemiol. 1995, 5, 108-118. [CrossRef]

62. Venn, B.J.; Green, T.J. Glycemic index and glycemic load: Measurement issues and their effect on diet-disease relationships. Eur. J. Clin. Nutr. 2007, 61, S122-S131. [CrossRef]

63. Martínez-González, M.A.; Gea, A.; Ruiz-Canela, M. The Mediterranean Diet and Cardiovascular Health. Circ. Res. 2019, 124, 779-798. [CrossRef]

64. Guenther, P.M.; Kirkpatrick, S.I.; Reedy, J.; Krebs-Smith, S.M.; Buckman, D.W.; Dodd, K.W.; Casavale, K.O.; Carroll, R.J. The Healthy Eating Index-2010 is a valid and reliable measure of diet quality according to the 2010 Dietary Guidelines for Americans. J. Nutr. 2014, 144, 399-407. [CrossRef]

65. Chiuve, S.E.; Fung, T.T.; Rimm, E.B.; Hu, F.B.; McCullough, M.L.; Wang, M.; Stampfer, M.J.; Willett, W.C. Alternative dietary indices both strongly predict risk of chronic disease. J. Nutr. 2012, 142, 1009-1018. [CrossRef]

66. Brauer, P.; Royall, D.; Rodrigues, A. Use of the Healthy Eating Index in Intervention Studies for Cardiometabolic Risk Conditions: A Systematic Review. Adv. Nutr. 2021. [CrossRef] [PubMed]

67. Murrin, C.; Shrivastava, A.; Kelleher, C.C.; Lifeways Cross-generation Cohort Study Steering Group. Maternal macronutrient intake during pregnancy and 5 years postpartum and associations with child weight status aged five. Eur. J. Clin. Nutr. 2013, 67, 670-679. [CrossRef]

68. Chia, A.-R.; Chen, L.-W.; Lai, J.S.; Wong, C.H.; Neelakantan, N.; van Dam, R.M.; Chong, M.F.-F. Maternal Dietary Patterns and Birth Outcomes: A Systematic Review and Meta-Analysis. Adv. Nutr. 2019, 10, 685-695. [CrossRef] [PubMed]

69. Aubert, A.M.; Forhan, A.; de Lauzon-Guillain, B.; Chen, L.W.; Polanska, K.; Hanke, W.; Jankowska, A.; Mensink-Bout, S.M.; Duijts, L.; Suderman, M.; et al. Deriving the Dietary Approaches to Stop Hypertension (DASH) Score in Women from Seven Pregnancy Cohorts from the European ALPHABET Consortium. Nutrients 2019, 11, 2706. [CrossRef]

70. Eckl, M.R.; Brouwer-Brolsma, E.M.; Küpers, L.K. Maternal Adherence to the Mediterranean Diet during Pregnancy: A Review of Commonly Used a priori Indexes. Nutrients 2021, 13, 582. [CrossRef] [PubMed] 
71. Trichopoulou, A.; Costacou, T.; Bamia, C.; Trichopoulos, D. Adherence to a Mediterranean diet and survival in a Greek population. N. Engl. J. Med. 2003, 348, 2599-2608. [CrossRef]

72. Serra-Majem, L.; Ribas, L.; Ngo, J.; Ortega, R.M.; García, A.; Pérez-Rodrigo, C.; Aranceta, J. Food, youth and the Mediterranean diet in Spain. Development of KIDMED, Mediterranean Diet Quality Index in children and adolescents. Public Health Nutr. 2004, 7, 931-935. [CrossRef] [PubMed]

73. Haugen, M.; Meltzer, H.M.; Brantsaeter, A.L.; Mikkelsen, T.; Osterdal, M.L.; Alexander, J.; Olsen, S.F.; Bakketeig, L. Mediterraneantype diet and risk of preterm birth among women in the Norwegian Mother and Child Cohort Study (MoBa): A prospective cohort study. Acta Obstet. Gynecol. Scand. 2008, 87, 319-324. [CrossRef] [PubMed]

74. Khoury, J.; Henriksen, T.; Christophersen, B.; Tonstad, S. Effect of a cholesterol-lowering diet on maternal, cord, and neonatal lipids, and pregnancy outcome: A randomized clinical trial. Am. J. Obstet. Gynecol. 2005, 193, 1292-1301. [CrossRef] [PubMed]

75. Rifas-Shiman, S.L.; Rich-Edwards, J.W.; Kleinman, K.P.; Oken, E.; Gillman, M.W. Dietary quality during pregnancy varies by maternal characteristics in Project Viva: A US cohort. J. Am. Diet. Assoc. 2009, 109, 1004-1011. [CrossRef]

76. Han, C.Y.; Colega, M.; Quah, E.P.L.; Chan, Y.H.; Godfrey, K.M.; Kwek, K.; Saw, S.-M.; Gluckman, P.D.; Chong, Y.-S.; Chong, M.F.-F.; et al. A healthy eating index to measure diet quality in pregnant women in Singapore: A cross-sectional study. BMC Nutr. 2015, 1, 39. [CrossRef]

77. Asemi, Z.; Tabassi, Z.; Samimi, M.; Fahiminejad, T.; Esmaillzadeh, A. Favourable effects of the Dietary Approaches to Stop Hypertension diet on glucose tolerance and lipid profiles in gestational diabetes: A randomised clinical trial. Br. J. Nutr. 2013, 109, 2024-2030. [CrossRef] [PubMed]

78. Asemi, Z.; Samimi, M.; Tabassi, Z.; Esmaillzadeh, A. The effect of DASH diet on pregnancy outcomes in gestational diabetes: A randomized controlled clinical trial. Eur. J. Clin. Nutr. 2014, 68, 490-495. [CrossRef] [PubMed]

79. Courtney, A.U.; O’Brien, E.C.; Crowley, R.K.; Geraghty, A.A.; Brady, M.B.; Kilbane, M.T.; Twomey, P.J.; McKenna, M.J.; McAuliffe, F.M. DASH (Dietary Approaches to Stop Hypertension) dietary pattern and maternal blood pressure in pregnancy. J. Hum. Nutr. Diet. 2020, 33, 686-697. [CrossRef] [PubMed]

80. Amati, F.; Hassounah, S.; Swaka, A. The Impact of Mediterranean Dietary Patterns During Pregnancy on Maternal and Offspring Health. Nutrients 2019, 11, 1098. [CrossRef]

81. Walsh, J.M.; McGowan, C.A.; Mahony, R.; Foley, M.E.; McAuliffe, F.M. Low glycaemic index diet in pregnancy to prevent macrosomia (ROLO study): Randomised control trial. BMJ. 2012, 345, e5605. [CrossRef]

82. Jiang, F.; Li, Y.; Xu, P.; Li, J.; Chen, X.; Yu, H.; Gao, B.; Xu, B.; Li, X.; Chen, W. The efficacy of the Dietary Approaches to Stop Hypertension diet with respect to improving pregnancy outcomes in women with hypertensive disorders. J. Hum. Nutr. Diet. 2019, 32, 713-718. [CrossRef]

83. Knudsen, V.K.; Heitmann, B.L.; Halldorsson, T.I.; Sørensen, T.I.; Olsen, S.F. Maternal dietary glycaemic load during pregnancy and gestational weight gain, birth weight and postpartum weight retention: A study within the Danish National Birth Cohort. Br. J. Nutr. 2013, 109, 1471-1478. [CrossRef] [PubMed]

84. Sen, S.; Rifas-Shiman, S.L.; Shivappa, N.; Wirth, M.D.; Hebert, J.R.; Gold, D.R.; Gillman, M.W.; Oken, E. Associations of prenatal and early life dietary inflammatory potential with childhood adiposity and cardiometabolic risk in Project Viva. Pediatr. Obes. 2018, 13, 292-300. [CrossRef] [PubMed]

85. Segovia, S.A.; Vickers, M.H.; Gray, C.; Reynolds, C.M. Maternal obesity, inflammation, and developmental programming. BioMed. Res. Int. 2014, 2014, 418975. [CrossRef] [PubMed]

86. Moore, B.F.; Sauder, K.A.; Starling, A.P.; Hébert, J.R.; Shivappa, N.; Ringham, B.M.; Glueck, D.H.; Dabelea, D. Proinflammatory Diets during Pregnancy and Neonatal Adiposity in the Healthy Start Study. J. Pediatr. 2018, 195, 121-127.e122. [CrossRef]

87. Chen, L.W.; Aubert, A.M.; Shivappa, N.; Bernard, J.Y.; Mensink-Bout, S.M.; Geraghty, A.A.; Mehegan, J.; Suderman, M.; Polanska, K.; Hanke, W.; et al. Associations of maternal dietary inflammatory potential and quality with offspring birth outcomes: An individual participant data pooled analysis of 7 European cohorts in the ALPHABET consortium. PLoS Med. 2021, 18, e1003491. [CrossRef]

88. Timmermans, S.; Steegers-Theunissen, R.P.; Vujkovic, M.; den Breeijen, H.; Russcher, H.; Lindemans, J.; Mackenbach, J.; Hofman, A.; Lesaffre, E.E.; Jaddoe, V.V.; et al. The Mediterranean diet and fetal size parameters: The Generation R Study. Br. J. Nutr. 2012, 108, 1399-1409. [CrossRef]

89. Chatzi, L.; Mendez, M.; Garcia, R.; Roumeliotaki, T.; Ibarluzea, J.; Tardón, A.; Amiano, P.; Lertxundi, A.; Iñiguez, C.; Vioque, J.; et al. Mediterranean diet adherence during pregnancy and fetal growth: INMA (Spain) and RHEA (Greece) mother-child cohort studies. Br. J. Nutr. 2012, 107, 135-145. [CrossRef]

90. Saunders, L.; Guldner, L.; Costet, N.; Kadhel, P.; Rouget, F.; Monfort, C.; Thomé, J.P.; Multigner, L.; Cordier, S. Effect of a Mediterranean diet during pregnancy on fetal growth and preterm delivery: Results from a French Caribbean Mother-Child Cohort Study (TIMOUN). Paediatr. Perinat. Epidemiol. 2014, 28, 235-244. [CrossRef]

91. Mikkelsen, T.B.; Osterdal, M.L.; Knudsen, V.K.; Haugen, M.; Meltzer, H.M.; Bakketeig, L.; Olsen, S.F. Association between a Mediterranean-type diet and risk of preterm birth among Danish women: A prospective cohort study. Acta Obstet. Gynecol. Scand. 2008, 87, 325-330. [CrossRef]

92. Yisahak, S.F.; Mumford, S.L.; Grewal, J.; Li, M.; Zhang, C.; Grantz, K.L.; Hinkle, S.N. Maternal diet patterns during early pregnancy in relation to neonatal outcomes. Am. J. Clin. Nutr. 2021. [CrossRef] [PubMed] 
93. Peraita-Costa, I.; Llopis-González, A.; Perales-Marín, A.; Diago, V.; Soriano, J.M.; Llopis-Morales, A.; Morales-Suárez-Varela, M. Maternal profile according to Mediterranean diet adherence and small for gestational age and preterm newborn outcomes. Public Health Nutr. 2020, 24, 1372-1384. [CrossRef]

94. Martínez-Galiano, J.M.; Olmedo-Requena, R.; Barrios-Rodríguez, R.; Amezcua-Prieto, C.; Bueno-Cavanillas, A.; Salcedo-Bellido, I.; Jimenez-Moleon, J.J.; Delgado-Rodríguez, M. Effect of Adherence to a Mediterranean Diet and Olive Oil Intake during Pregnancy on Risk of Small for Gestational Age Infants. Nutrients 2018, 10, 1234. [CrossRef] [PubMed]

95. Martínez-González, M.A.; Fernández-Jarne, E.; Serrano-Martínez, M.; Wright, M.; Gomez-Gracia, E. Development of a short dietary intake questionnaire for the quantitative estimation of adherence to a cardioprotective Mediterranean diet. Eur. J. Clin. Nutr. 2004, 58, 1550-1552. [CrossRef]

96. Panagiotakos, D.B.; Pitsavos, C.; Arvaniti, F.; Stefanadis, C. Adherence to the Mediterranean food pattern predicts the prevalence of hypertension, hypercholesterolemia, diabetes and obesity, among healthy adults; the accuracy of the MedDietScore. Prev. Med. 2007, 44, 335-340. [CrossRef] [PubMed]

97. Gómez Roig, M.D.; Mazarico, E.; Ferrero, S.; Montejo, R.; Ibáñez, L.; Grima, F.; Vela, A. Differences in dietary and lifestyle habits between pregnant women with small fetuses and appropriate-for-gestational-age fetuses. J. Obstet. Gynaecol. Res. 2017, 43, 1145-1151. [CrossRef]

98. Biagi, C.; Nunzio, M.D.; Bordoni, A.; Gori, D.; Lanari, M. Effect of Adherence to Mediterranean Diet during Pregnancy on Children's Health: A Systematic Review. Nutrients 2019, 11, 997. [CrossRef]

99. Rodríguez-Bernal, C.L.; Rebagliato, M.; Iñiguez, C.; Vioque, J.; Navarrete-Muñoz, E.M.; Murcia, M.; Bolumar, F.; Marco, A.; Ballester, F. Diet quality in early pregnancy and its effects on fetal growth outcomes: The Infancia y Medio Ambiente (Childhood and Environment) Mother and Child Cohort Study in Spain. Am. J. Clin. Nutr. 2010, 91, 1659-1666. [CrossRef]

100. Badon, S.E.; Miller, R.S.; Qiu, C.; Sorensen, T.K.; Williams, M.A.; Enquobahrie, D.A. Maternal healthy lifestyle during early pregnancy and offspring birthweight: Differences by offspring sex. J. Matern. Fetal Neonatal. Med. 2018, 31, 1111-1117. [CrossRef]

101. Poon, A.K.; Yeung, E.; Boghossian, N.; Albert, P.S.; Zhang, C. Maternal Dietary Patterns during Third Trimester in Association with Birthweight Characteristics and Early Infant Growth. Science 2013, 2013, 786409. [CrossRef] [PubMed]

102. Shapiro, A.L.; Kaar, J.L.; Crume, T.L.; Starling, A.P.; Siega-Riz, A.M.; Ringham, B.M.; Glueck, D.H.; Norris, J.M.; Barbour, L.A.; Friedman, J.E.; et al. Maternal diet quality in pregnancy and neonatal adiposity: The Healthy Start Study. Int. J. Obes. 2016, 40, 1056-1062. [CrossRef]

103. Zhu, Y.; Hedderson, M.M.; Sridhar, S.; Xu, F.; Feng, J.; Ferrara, A. Poor diet quality in pregnancy is associated with increased risk of excess fetal growth: A prospective multi-racial/ethnic cohort study. Int. J. Epidemiol. 2019, 48, 423-432. [CrossRef]

104. Navarro, P.; Mehegan, J.; Murrin, C.M.; Kelleher, C.C.; Phillips, C.M. Adherence to the Healthy Eating Index-2015 across Generations Is Associated with Birth Outcomes and Weight Status at Age 5 in the Lifeways Cross-Generation Cohort Study. Nutrients 2019, 11, 928. [CrossRef]

105. Chia, A.R.; Tint, M.T.; Han, C.Y.; Chen, L.W.; Colega, M.; Aris, I.M.; Chua, M.C.; Tan, K.H.; Yap, F.; Shek, L.P.; et al. Adherence to a healthy eating index for pregnant women is associated with lower neonatal adiposity in a multiethnic Asian cohort: The Growing Up in Singapore Towards healthy Outcomes (GUSTO) Study. Am. J. Clin. Nutr. 2018, 107, 71-79. [CrossRef]

106. McCullough, M.L.; Feskanich, D.; Stampfer, M.J.; Giovannucci, E.L.; Rimm, E.B.; Hu, F.B.; Spiegelman, D.; Hunter, D.J.; Colditz, G.A.; Willett, W.C. Diet quality and major chronic disease risk in men and women: Moving toward improved dietary guidance. Am. J. Clin. Nutr. 2002, 76, 1261-1271. [CrossRef]

107. Li, S.; Gan, Y.; Chen, M.; Wang, M.; Wang, X.; Santos, H.O.; Okunade, K.; Kathirgamathamby, V. Effects of the Dietary Approaches to Stop Hypertension (DASH) on Pregnancy/Neonatal Outcomes and Maternal Glycemic Control: A Systematic Review and Meta-analysis of Randomized Clinical Trials. Complementary Ther. Med. 2020, 54, 102551. [CrossRef]

108. Vesco, K.K.; Karanja, N.; King, J.C.; Gillman, M.W.; Leo, M.C.; Perrin, N.; McEvoy, C.T.; Eckhardt, C.L.; Smith, K.S.; Stevens, V.J. Efficacy of a group-based dietary intervention for limiting gestational weight gain among obese women: A randomized trial. Obesity 2014, 22, 1989-1996. [CrossRef]

109. Van Horn, L.; Peaceman, A.; Kwasny, M.; Vincent, E.; Fought, A.; Josefson, J.; Spring, B.; Neff, L.M.; Gernhofer, N. Dietary Approaches to Stop Hypertension Diet and Activity to Limit Gestational Weight: Maternal Offspring Metabolics Family Intervention Trial, a Technology Enhanced Randomized Trial. Am. J. Prev. Med. 2018, 55, 603-614. [CrossRef] [PubMed]

110. Fulay, A.P.; Rifas-Shiman, S.L.; Oken, E.; Perng, W. Associations of the dietary approaches to stop hypertension (DASH) diet with pregnancy complications in Project Viva. Eur. J. Clin. Nutr. 2018, 72, 1385-1395. [CrossRef] [PubMed]

111. Martin, C.L.; Sotres-Alvarez, D.; Siega-Riz, A.M. Maternal Dietary Patterns during the Second Trimester Are Associated with Preterm Birth. J. Nutr. 2015, 145, 1857-1864. [CrossRef] [PubMed]

112. Perichart-Perera, O.; Balas-Nakash, M.; Rodríguez-Cano, A.; Legorreta-Legorreta, J.; Parra-Covarrubias, A.; Vadillo-Ortega, F. Low Glycemic Index Carbohydrates versus All Types of Carbohydrates for Treating Diabetes in Pregnancy: A Randomized Clinical Trial to Evaluate the Effect of Glycemic Control. Int. J. Endocrinol. 2012, 2012, 296017. [CrossRef] [PubMed]

113. Horan, M.K.; McGowan, C.A.; Gibney, E.R.; Byrne, J.; Donnelly, J.M.; McAuliffe, F.M. Maternal Nutrition and Glycaemic Index during Pregnancy Impacts on Offspring Adiposity at 6 Months of Age-Analysis from the ROLO Randomised Controlled Trial. Nutrients 2016, 8, 7. [CrossRef] 
114. Moses, R.G.; Casey, S.A.; Quinn, E.G.; Cleary, J.M.; Tapsell, L.C.; Milosavljevic, M.; Petocz, P.; Brand-Miller, J.C. Pregnancy and Glycemic Index Outcomes study: Effects of low glycemic index compared with conventional dietary advice on selected pregnancy outcomes. Am. J. Clin. Nutr. 2014, 99, 517-523. [CrossRef]

115. Callanan, S.; Yelverton, C.A.; Geraghty, A.A.; O’Brien, E.C.; Donnelly, J.M.; Larkin, E.; Horan, M.K.; Mehegan, J.; McAuliffe, F.M. The association of a low glycaemic index diet in pregnancy with child body composition at 5 years of age: A secondary analysis of the ROLO study. Pediatric Obes. 2021, e12820. [CrossRef]

116. Strohmaier, S.; Bogl, L.H.; Eliassen, A.H.; Massa, J.; Field, A.E.; Chavarro, J.E.; Ding, M.; Tamimi, R.M.; Schernhammer, E. Maternal healthful dietary patterns during peripregnancy and long-term overweight risk in their offspring. Eur. J. Epidemiol. 2020, 35, 283-293. [CrossRef]

117. Maslova, E.; Hansen, S.; Grunnet, L.G.; Strøm, M.; Bjerregaard, A.A.; Hjort, L.; Kampmann, F.B.; Madsen, C.M.; Thuesen, A.C.B.; Bech, B.H.; et al. Maternal glycemic index and glycemic load in pregnancy and offspring metabolic health in childhood and adolescence-A cohort study of 68,471 mother-offspring dyads from the Danish National Birth Cohort. Eur. J. Clin. Nutr. 2019, 73, 1049-1062. [CrossRef]

118. Gonzalez-Nahm, S.; Hoyo, C.; Østbye, T.; Neelon, B.; Allen, C.; Benjamin-Neelon, S.E. Associations of maternal diet with infant adiposity at birth, 6 months and 12 months. BMJ Open 2019, 9, e030186. [CrossRef]

119. Tahir, M.J.; Haapala, J.L.; Foster, L.P.; Duncan, K.M.; Teague, A.M.; Kharbanda, E.O.; McGovern, P.M.; Whitaker, K.M.; Rasmussen, K.M.; Fields, D.A.; et al. Higher Maternal Diet Quality during Pregnancy and Lactation Is Associated with Lower Infant Weight-For-Length, Body Fat Percent, and Fat Mass in Early Postnatal Life. Nutrients 2019, 11, 632. [CrossRef]

120. Chatzi, L.; Rifas-Shiman, S.L.; Georgiou, V.; Joung, K.E.; Koinaki, S.; Chalkiadaki, G.; Margioris, A.; Sarri, K.; Vassilaki, M.; Vafeiadi, M.; et al. Adherence to the Mediterranean diet during pregnancy and offspring adiposity and cardiometabolic traits in childhood. Pediatric Obes. 2017, 12, 47-56. [CrossRef] [PubMed]

121. Fernández-Barrés, S.; Romaguera, D.; Valvi, D.; Martínez, D.; Vioque, J.; Navarrete-Muñoz, E.M.; Amiano, P.; Gonzalez-Palacios, S.; Guxens, M.; Pereda, E.; et al. Mediterranean dietary pattern in pregnant women and offspring risk of overweight and abdominal obesity in early childhood: The INMA birth cohort study. Pediatric Obes. 2016, 11, 491-499. [CrossRef] [PubMed]

122. Okubo, H.; Crozier, S.R.; Harvey, N.C.; Godfrey, K.M.; Inskip, H.M.; Cooper, C.; Robinson, S.M. Maternal dietary glycemic index and glycemic load in early pregnancy are associated with offspring adiposity in childhood: The Southampton Women's Survey. Am. J. Clin. Nutr. 2014, 100, 676-683. [CrossRef] [PubMed]

123. Chen, L.-W.; Aubert, A.M.; Shivappa, N.; Bernard, J.Y.; Mensink-Bout, S.M.; Geraghty, A.A.; Mehegan, J.; Suderman, M.; Polanska, K.; Hanke, W.; et al. Maternal dietary quality, inflammatory potential and childhood adiposity: An individual participant data pooled analysis of seven European cohorts in the ALPHABET consortium. BMC Med. 2021, 19, 33. [CrossRef]

124. Forkert, E.C.O.; Rendo-Urteaga, T.; Nascimento-Ferreira, M.V.; de Moraes, A.C.F.; Moreno, L.A.; de Carvalho, H.B. Abdominal obesity and cardiometabolic risk in children and adolescents, are we aware of their relevance? Nutrire 2016, 41, 15. [CrossRef]

125. Lee, H.; Lee, I.S.; Choue, R. Obesity, inflammation and diet. Pediatr. Gastroenterol. Hepatol. Nutr. 2013, 16, 143-152. [CrossRef]

126. Donahue, S.M.; Rifas-Shiman, S.L.; Gold, D.R.; Jouni, Z.E.; Gillman, M.W.; Oken, E. Prenatal fatty acid status and child adiposity at age 3 y: Results from a US pregnancy cohort. Am. J. Clin. Nutr. 2011, 93, 780-788. [CrossRef] [PubMed]

127. Burton, G.J.; Fowden, A.L.; Thornburg, K.L. Placental Origins of Chronic Disease. Physiol. Rev. 2016, 96, 1509-1565. [CrossRef] [PubMed]

128. Desoye, G.; Cervar-Zivkovic, M. Diabetes Mellitus, Obesity, and the Placenta. Obs. Gynecol. Clin. N. Am. 2020, 47, 65-79. [CrossRef]

129. Ten-Teachers. Obstetrics, 20th ed.; CRC Press Taylor \& Francis Group: Boca Raton, FL, USA, 2017; pp. 86-92.

130. Brett, K.E.; Ferraro, Z.M.; Yockell-Lelievre, J.; Gruslin, A.; Adamo, K.B. Maternal-fetal nutrient transport in pregnancy pathologies: The role of the placenta. Int. J. Mol. Sci. 2014, 15, 16153-16185. [CrossRef]

131. Larsen, S.; Bjelland, E.K.; Haavaldsen, C.; Eskild, A. Placental weight in pregnancies with high or low hemoglobin concentrations. Eur. J. Obstet. Gynecol. Reprod. Biol. 2016, 206, 48-52. [CrossRef] [PubMed]

132. Eriksson, J.G.; Gelow, J.; Thornburg, K.L.; Osmond, C.; Laakso, M.; Uusitupa, M.; Lindi, V.; Kajantie, E.; Barker, D.J.P. Long-Term Effects of Placental Growth on Overweight and Body Composition. Int. J. Pediatrics 2012, 2012, 324185. [CrossRef] [PubMed]

133. Cetin, I.; Berti, C.; Calabrese, S. Role of micronutrients in the periconceptional period. Hum. Reprod. Update 2010, 16, 80-95. [CrossRef] [PubMed]

134. Desoye, G. The Human Placenta in Diabetes and Obesity: Friend or Foe? The 2017 Norbert Freinkel Award Lecture. Diabetes Care 2018, 41, 1362-1369. [CrossRef] [PubMed]

135. Meakin, A.S.; Cuffe, J.S.M.; Darby, J.R.T.; Morrison, J.L.; Clifton, V.L. Let's Talk about Placental Sex, Baby: Understanding Mechanisms That Drive Female- and Male-Specific Fetal Growth and Developmental Outcomes. Int. J. Mol. Sci. 2021, 22, 6386. [CrossRef] [PubMed]

136. Donnelly, J.M.T.; Horan, M.; Segurado, R.; Mooney, E.E.; French, S.; Molloy, E.J.; McAuliffe, F.M. Sexual dimorphism and the placenta-results from the ROLO kids study. J. Matern. Fetal Neonatal. Med. 2020, 1-7. [CrossRef] [PubMed]

137. Bernadette, C.B.; Dexter, J.L.H.; Rebecca, L.J. Effects of micronutrients on placental function: Evidence from clinical studies to animal models. Reproduction 2018, 156, R69-R82. [CrossRef]

138. Bayol, S.A.; Farrington, S.J.; Stickland, N.C. A maternal 'junk food' diet in pregnancy and lactation promotes an exacerbated taste for 'junk food' and a greater propensity for obesity in rat offspring. Br. J. Nutr. 2007, 98, 843-851. [CrossRef] [PubMed] 
139. Dekker Nitert, M.; Vaswani, K.; Hum, M.; Chan, H.-W.; Wood-Bradley, R.; Henry, S.; Armitage, J.A.; Mitchell, M.D.; Rice, G.E. Maternal high-fat diet alters expression of pathways of growth, blood supply and arachidonic acid in rat placenta. J. Nutr. Sci. 2014, 2, e41. [CrossRef]

140. Wentzel, P.; Eriksson, U.J.; Herrera, E. High-fat diet in pregnant rats and adverse fetal outcome. Upsala J. Med. Sci. 2019, 124, 125-134. [CrossRef]

141. Tellechea, M.L.; Mensegue, M.F.; Pirola, C.J. The Association between High Fat Diet around Gestation and Metabolic Syndromerelated Phenotypes in Rats: A Systematic Review and Meta-Analysis. Sci. Rep. 2017, 7, 5086. [CrossRef] [PubMed]

142. Kereliuk, S.M.; Brawerman, G.M.; Dolinsky, V.W. Maternal Macronutrient Consumption and the Developmental Origins of Metabolic Disease in the Offspring. Int. J. Mol. Sci 2017, 18, 1451. [CrossRef] [PubMed]

143. Toblli, J.E.; Cao, G.; Oliveri, L.; Angerosa, M. Effects of iron deficiency anemia and its treatment with iron polymaltose complex in pregnant rats, their fetuses and placentas: Oxidative stress markers and pregnancy outcome. Placenta 2012, 33, 81-87. [CrossRef]

144. Rosario, F.J.; Nathanielsz, P.W.; Powell, T.L.; Jansson, T. Maternal folate deficiency causes inhibition of mTOR signaling, downregulation of placental amino acid transporters and fetal growth restriction in mice. Sci. Rep. 2017, 7, 3982. [CrossRef]

145. Parisi, F.; Savasi, V.M.; di Bartolo, I.; Mandia, L.; Cetin, I. Associations between First Trimester Maternal Nutritional Score, Early Markers of Placental Function, and Pregnancy Outcome. Nutrients 2020, 12, 1799. [CrossRef]

146. Sharma, S.S.; Greenwood, D.C.; Simpson, N.A.B.; Cade, J.E. Is dietary macronutrient composition during pregnancy associated with offspring birth weight? An observational study. Br. J. Nutr. 2018, 119, 330-339. [CrossRef]

147. Schwingshackl, L.; Zähringer, J.; Beyerbach, J.; Werner, S.W.; Heseker, H.; Koletzko, B.; Meerpohl, J.J. Total Dietary Fat Intake, Fat Quality, and Health Outcomes: A Scoping Review of Systematic Reviews of Prospective Studies. Ann. Nutr. Metab. 2021, 77, 4-15. [CrossRef]

148. Kabaran, S.; Besler, H.T. Do fatty acids affect fetal programming? J. Health Popul. Nutr. 2015, 33, 14. [CrossRef] [PubMed]

149. Herring, C.M.; Bazer, F.W.; Johnson, G.A.; Wu, G. Impacts of maternal dietary protein intake on fetal survival, growth, and development. Exp. Biol. Med. 2018, 243, 525-533. [CrossRef] [PubMed]

150. Hindmarsh, P.C.; Geary, M.P.; Rodeck, C.H.; Jackson, M.R.; Kingdom, J.C. Effect of early maternal iron stoRes. on placental weight and structure. Lancet 2000, 356, 719-723. [CrossRef]

151. Wiertsema Clarissa, J.; Mensink-Bout Sara, M.; Duijts, L.; Mulders Annemarie, G.M.G.J.; Jaddoe Vincent, W.V.; Gaillard, R. Associations of DASH Diet in Pregnancy With Blood Pressure Patterns, Placental Hemodynamics, and Gestational Hypertensive Disorders. J. Am. Heart Assoc. 2021, 10, e017503. [CrossRef]

152. Deans, C.; Maggert, K.A. What do you mean, "epigenetic"? Genetics 2015, 199, 887-896. [CrossRef] [PubMed]

153. Aguilera, O.; Fernández, A.F.; Muñoz, A.; Fraga, M.F. Epigenetics and environment: A complex relationship. J. Appl. Physiol. 2010, 109, 243-251. [CrossRef]

154. Weinhold, B. Epigenetics: The Science of Change. Environ. Health Perspect. 2006, 114, A160-A167. [CrossRef]

155. Gibney, E.R.; Nolan, C.M. Epigenetics and gene expression. Heredity 2010, 105, 4-13. [CrossRef]

156. Heijmans, B.T.; Tobi, E.W.; Lumey, L.H.; Slagboom, P.E. The epigenome: Archive of the prenatal environment. Epigenetics 2009, 4, 526-531. [CrossRef]

157. Waterland, R.A.; Michels, K.B. Epigenetic epidemiology of the developmental origins hypothesis. Annu. Rev. Nutr. 2007, 27, 363-388. [CrossRef] [PubMed]

158. Słupecka-Ziemilska, M.; Wychowański, P.; Puzianowska-Kuznicka, M. Gestational Diabetes Mellitus Affects Offspring's Epigenome. Is There a Way to Reduce the Negative Consequences? Nutrients 2020, 12, 2792. [CrossRef]

159. Wajed, S.A.; Laird, P.W.; DeMeester, T.R. DNA methylation: An alternative pathway to cancer. Ann. Surg. 2001, 234, 10-20. [CrossRef]

160. Waterland, R.A.; Jirtle, R.L. Transposable Elements: Targets for Early Nutritional Effects on Epigenetic Gene Regulation. Mol. Cell. Biol. 2003, 23, 5293-5300. [CrossRef] [PubMed]

161. Steegers-Theunissen, R.P.; Twigt, J.; Pestinger, V.; Sinclair, K.D. The periconceptional period, reproduction and long-term health of offspring: The importance of one-carbon metabolism. Hum. Reprod. Update 2013, 19, 640-655. [CrossRef] [PubMed]

162. Pauwels, S.; Ghosh, M.; Duca, R.C.; Bekaert, B.; Freson, K.; Huybrechts, I.; Langie, S.A.S.; Koppen, G.; Devlieger, R.; Godderis, L. Maternal intake of methyl-group donors affects DNA methylation of metabolic genes in infants. Clin. Epigenetics 2017, 9, 16. [CrossRef] [PubMed]

163. Dominguez-Salas, P.; Moore, S.E.; Baker, M.S.; Bergen, A.W.; Cox, S.E.; Dyer, R.A.; Fulford, A.J.; Guan, Y.; Laritsky, E.; Silver, M.J.; et al. Maternal nutrition at conception modulates DNA methylation of human metastable epialleles. Nat. Commun. 2014, 5, 3746. [CrossRef]

164. Waterland, R.A.; Kellermayer, R.; Laritsky, E.; Rayco-Solon, P.; Harris, R.A.; Travisano, M.; Zhang, W.; Torskaya, M.S.; Zhang, J.; Shen, L.; et al. Season of conception in rural gambia affects DNA methylation at putative human metastable epialleles. PLoS Genet. 2010, 6, e1001252. [CrossRef] [PubMed]

165. Rakyan, V.K.; Blewitt, M.E.; Druker, R.; Preis, J.I.; Whitelaw, E. Metastable epialleles in mammals. Trends Genet 2002, 18, 348-351. [CrossRef]

166. Ba, Y.; Yu, H.; Liu, F.; Geng, X.; Zhu, C.; Zhu, Q.; Zheng, T.; Ma, S.; Wang, G.; Li, Z.; et al. Relationship of folate, vitamin B12 and methylation of insulin-like growth factor-II in maternal and cord blood. Eur. J. Clin. Nutr. 2011, 65, 480-485. [CrossRef] [PubMed] 
167. Haggarty, P.; Hoad, G.; Campbell, D.M.; Horgan, G.W.; Piyathilake, C.; McNeill, G. Folate in pregnancy and imprinted gene and repeat element methylation in the offspring. Am. J. Clin. Nutr. 2013, 97, 94-99. [CrossRef] [PubMed]

168. Caffrey, A.; Irwin, R.E.; McNulty, H.; Strain, J.J.; Lees-Murdock, D.J.; McNulty, B.A.; Ward, M.; Walsh, C.P.; Pentieva, K. Genespecific DNA methylation in newborns in response to folic acid supplementation during the second and third trimesters of pregnancy: Epigenetic analysis from a randomized controlled trial. Am. J. Clin. Nutr. 2018, 107, 566-575. [CrossRef] [PubMed]

169. Franzago, M.; Fraticelli, F.; Stuppia, L.; Vitacolonna, E. Nutrigenetics, epigenetics and gestational diabetes: Consequences in mother and child. Epigenetics 2019, 14, 215-235. [CrossRef]

170. Geraghty, A.A.; Sexton-Oates, A.; O’Brien, E.C.; Alberdi, G.; Fransquet, P.; Saffery, R.; McAuliffe, F.M. A Low Glycaemic Index Diet in Pregnancy Induces DNA Methylation Variation in Blood of Newborns: Results from the ROLO Randomised Controlled Trial. Nutrients 2018, 10, 455. [CrossRef]

171. Geraghty, A.A.; Sexton-Oates, A.; O’Brien, E.C.; Saffery, R.; McAuliffe, F.M. Epigenetic Patterns in Five-Year-Old Children Exposed to a Low Glycemic Index Dietary Intervention during Pregnancy: Results from the ROLO Kids Study. Nutrients 2020, 12, 3602. [CrossRef] [PubMed]

172. Yan, W.; Zhang, Y.; Wang, L.; Yang, W.; Li, C.; Wang, L.; Gu, P.; Xia, Y.; Yan, J.; Shen, Y.; et al. Maternal dietary glycaemic change during gestation influences insulin-related gene methylation in the placental tissue: A genome-wide methylation analysis. Genes Nutr. 2019, 14, 17. [CrossRef]

173. Antoun, E.; Kitaba, N.T.; Titcombe, P.; Dalrymple, K.V.; Garratt, E.S.; Barton, S.J.; Murray, R.; Seed, P.T.; Holbrook, J.D.; Kobor, M.S.; et al. Maternal dysglycaemia, changes in the infant's epigenome modified with a diet and physical activity intervention in pregnancy: Secondary analysis of a randomised control trial. PLoS Med. 2020, 17, e1003229. [CrossRef]

174. Zhang, Q.; Xiao, X.; Zheng, J.; Li, M.; Yu, M.; Ping, F.; Wang, T.; Wang, X. A Maternal High-Fat Diet Induces DNA Methylation Changes That Contribute to Glucose Intolerance in Offspring. Front. Endocrinol. 2019, 10, 871. [CrossRef]

175. Gali Ramamoorthy, T.; Allen, T.J.; Davies, A.; Harno, E.; Sefton, C.; Murgatroyd, C.; White, A. Maternal overnutrition programs epigenetic changes in the regulatory regions of hypothalamic Pomc in the offspring of rats. Int. J. Obes. 2018, 42, 1431-1444. [CrossRef]

176. Dudley, K.J.; Sloboda, D.M.; Connor, K.L.; Beltrand, J.; Vickers, M.H. Offspring of mothers fed a high fat diet display hepatic cell cycle inhibition and associated changes in gene expression and DNA methylation. PLoS ONE 2011, 6, e21662. [CrossRef] [PubMed]

177. Hanson, M.; Godfrey, K.M.; Lillycrop, K.A.; Burdge, G.C.; Gluckman, P.D. Developmental plasticity and developmental origins of non-communicable disease: Theoretical considerations and epigenetic mechanisms. Prog. Biophys. Mol. Biol. 2011, 106, 272-280. [CrossRef]

178. Lee, H.S. Impact of Maternal Diet on the Epigenome during In Utero Life and the Developmental Programming of Diseases in Childhood and Adulthood. Nutrients 2015, 7, 9492-9507. [CrossRef]

179. Heijmans, B.T.; Tobi, E.W.; Stein, A.D.; Putter, H.; Blauw, G.J.; Susser, E.S.; Slagboom, P.E.; Lumey, L.H. Persistent epigenetic differences associated with prenatal exposure to famine in humans. Proc. Natl. Acad. Sci. USA 2008, 105, 17046-17049. [CrossRef]

180. Martin, C.L.; Jima, D.; Sharp, G.C.; McCullough, L.E.; Park, S.S.; Gowdy, K.M.; Skaar, D.; Cowley, M.; Maguire, R.L.; Fuemmeler, B.; et al. Maternal pre-pregnancy obesity, offspring cord blood DNA methylation, and offspring cardiometabolic health in early childhood: An epigenome-wide association study. Epigenetics 2019, 14, 325-340. [CrossRef]

181. Sharp, G.C.; Lawlor, D.A.; Richmond, R.C.; Fraser, A.; Simpkin, A.; Suderman, M.; Shihab, H.A.; Lyttleton, O.; McArdle, W.; Ring, S.M.; et al. Maternal pre-pregnancy BMI and gestational weight gain, offspring DNA methylation and later offspring adiposity: Findings from the Avon Longitudinal Study of Parents and Children. Int. J. Epidemiol. 2015, 44, 1288-1304. [CrossRef] [PubMed]

182. Sharp, G.C.; Salas, L.A.; Monnereau, C.; Allard, C.; Yousefi, P.; Everson, T.M.; Bohlin, J.; Xu, Z.; Huang, R.C.; Reese, S.E.; et al Maternal BMI at the start of pregnancy and offspring epigenome-wide DNA methylation: Findings from the pregnancy and childhood epigenetics (PACE) consortium. Hum. Mol. Genet. 2017, 26, 4067-4085. [CrossRef] [PubMed]

183. Gonzalez-Nahm, S.; Mendez, M.; Robinson, W.; Murphy, S.K.; Hoyo, C.; Hogan, V.; Rowley, D. Low maternal adherence to a Mediterranean diet is associated with increase in methylation at the MEG3-IG differentially methylated region in female infants Environ. Epigenet. 2017, 3, dvx007. [CrossRef] [PubMed]

184. House, J.S.; Mendez, M.; Maguire, R.L.; Gonzalez-Nahm, S.; Huang, Z.; Daniels, J.; Murphy, S.K.; Fuemmeler, B.F.; Wright, F.A.; Hoyo, C. Periconceptional Maternal Mediterranean Diet Is Associated With Favorable Offspring Behaviors and Altered CpG Methylation of Imprinted Genes. Front. Cell Dev. Biol. 2018, 6, 107. [CrossRef] [PubMed]

185. Hoyo, C.; Murphy, S.K.; Jirtle, R.L. ImprInt. regulatory elements as epigenetic biosensors of exposure in epidemiological studies. J. Epidemiol. Community Health 2009, 63, 683-684. [CrossRef] [PubMed]

186. Robinson, D.P.; Klein, S.L. Pregnancy and pregnancy-associated hormones alter immune responses and disease pathogenesis. Horm. Behav. 2012, 62, 263-271. [CrossRef]

187. Campbell, J.M.; McPherson, N.O. Influence of increased paternal BMI on pregnancy and child health outcomes independent of maternal effects: A systematic review and meta-analysis. Obes. Res. Clin. Pract. 2019, 13, 511-521. [CrossRef]

188. Noor, N.; Cardenas, A.; Rifas-Shiman, S.L.; Pan, H.; Dreyfuss, J.M.; Oken, E.; Hivert, M.F.; James-Todd, T.; Patti, M.E.; Isganaitis, E. Association of Periconception Paternal Body Mass Index With Persistent Changes in DNA Methylation of Offspring in Childhood JAMA Netw. Open 2019, 2, e1916777. [CrossRef] [PubMed]

189. Fielding-Singh, P. Dining with dad: Fathers' influences on family food practices. Appetite 2017, 117, 98-108. [CrossRef] [PubMed] 
190. Broere-Brown, Z.A.; Baan, E.; Schalekamp-Timmermans, S.; Verburg, B.O.; Jaddoe, V.W.; Steegers, E.A. Sex-specific differences in fetal and infant growth patterns: A prospective population-based cohort study. Biol. Sex Differ. 2016, 7, 65. [CrossRef]

191. Phang, M.; Ross, J.; Raythatha, J.H.; Dissanayake, H.U.; McMullan, R.L.; Kong, Y.; Hyett, J.; Gordon, A.; Molloy, P.; Skilton, M.R. Epigenetic aging in newborns: Role of maternal diet. Am. J. Clin. Nutr. 2020, 111, 555-561. [CrossRef]

192. Lazarides, C.; Epel, E.S.; Lin, J.; Blackburn, E.H.; Voelkle, M.C.; Buss, C.; Simhan, H.N.; Wadhwa, P.D.; Entringer, S. Maternal pro-inflammatory state during pregnancy and newborn leukocyte telomere length: A prospective investigation. Brain Behav. Immun. 2019, 80, 419-426. [CrossRef]

193. Lee, Y.; Sun, D.; Ori, A.P.S.; Lu, A.T.; Seeboth, A.; Harris, S.E.; Deary, I.J.; Marioni, R.E.; Soerensen, M.; Mengel-From, J.; et al. Epigenome-wide association study of leukocyte telomere length. Aging 2019, 11, 5876-5894. [CrossRef] 